\title{
Sujeito e Ordem: Romantismo e Decisionismo no Pensamento de Carl Schmitt*
}

\author{
Bernardo Ferreira
}

$\mathrm{U}$ ma das características mais significativas do pensamento de Carl Schmitt ${ }^{1}$ nos anos 20 é o papel que a controvérsia desempenha na elaboração das suas idéias. Com efeito, como ele próprio observa em um texto de 1931, "todo conceito político é um conceito polêmico. Ele tem em vista um inimigo político e está determinado na sua posição espiritual, na sua força intelectual e no seu significado histórico pelo seu inimigo" (HP:5).

Um leitor atento dos trabalhos de Carl Schmitt não terá dificuldade em constatar que essa descrição da natureza dos conceitos políticos pode ser aplicada à própria atividade intelectual do autor. $\mathrm{O}$ conjunto da sua obra possui um caráter marcadamente polêmico e para cada um dos seus textos importantes é possível, com relativa facilidade, identificar um antagonismo concreto como motivo. Nesse sentido, o trecho citado não deixa de ser um testemunho da maneira como Schmitt encara sua própria obra jurídico-política e pode ser visto como uma espécie de declaração de princípios.

\footnotetext{
* Este artigo é uma versão resumida do segundo capítulo da minha tese de doutorado em Ciência Política, O Risco do Político: A Crítica ao Liberalismo na Obra da Carl Schmitt entre 1919-1933, defendida no IUPERJ em 2001.
}

DADOS - Revista de Ciências Sociais, Rio de Janeiro, Vol. 45, nº 4, 2002, pp. 599 a 648. 


\section{Bernardo Ferreira}

De fato, essa obra é polêmica porque a imagem de que as relações políticas estão determinadas pela possibilidade extrema da hostilidade entre grupos humanos se incorpora à própria estrutura de argumentação. A inimizade, em Carl Schmitt, é uma condição da elaboração da reflexão política, da sua construção polêmica a partir de um antagonista. Schmitt pensa contra um adversário, mas também por seu intermédio. Sendo assim, o inimigo não é a penas alguém, por assim dizer, situado fora, uma realidade exterior com a qual o pensamento se defronta. A inimizade tem um papel estrutural, ela é um ponto de vista epistemológico que, como tal, é interno ao processo de conhecimento. Nesse sentido, pode-se dizer que a atitude polêmica que marca a obra de Carl Schmitt resulta de uma concepção política do conhecimento. Em outros termos, a polêmica não é apenas a forma que esse pensamento assume ao se dirigir às circunstâncias políticas em que está inserido, não é apenas a maneira pela qual responde às questões do seu tempo e se confronta com o seu contexto intelectual; ela é uma atitude epistemológica por meio da qual a natureza da agonística da vida política se incorpora ao próprio ato do conhecer e se torna uma condição de possibilidade da criação teórica ${ }^{2}$.

Mais do que um dado da realidade empírica, o inimigo apresenta-se como um objeto do pensamento, como uma construção intelectual contra a qual Schmitt procura definir a sua própria posição teórica. O exercício de elaboração das próprias idéias exige, segundo esse ponto de vista, um colocar-se frente a frente com as idéias de um antagonista que é, antes de tudo, uma criação do próprio pensar. A determinação do inimigo é aqui uma premissa da criação teórica. Sob diversos aspectos, ele é uma espécie de duplo invertido da teoria política de Carl Schmitt, de modo que a forma da oposição binária implica não só a definição das características do inimigo em função da concepção da política apresentada por Schmitt, como também a definição desta última em contraposição àquelas características.

Este artigo pretende explorar essa concepção política do conhecimento político em Carl Schmitt, tomando como referência a constelação de conceitos que se articulam em torno da sua abordagem do romantismo e do decisionismo. Como espero mostrar ao longo da minha exposição, romantismo e decisionismo constituem, em Schmitt, universos conceituais contrapostos. Quero crer que a discussão de ambos em conjunto permitirá não só lançar luz sobre alguns aspectos do processo de construção do pensamento desse autor, como também sobre 
os vínculos estreitos entre a sua reflexão jurídico-política nos anos 20 e a crítica da civilização liberal-burguesa como expressão da modernidade.

\title{
A ORDEM DO SUJEITO
}

\author{
“Mas então, que se tornará o homem, sem Deus, \\ sem imortalidade? Tudo é permitido, \\ por conseqüência, tudo é lícito?" \\ Dostoievski - Os Irmãos Karamázovi
}

Publicado em 1919, o livro Politische Romantik (Romantismo Político) é o primeiro de um conjunto de importantes textos que Carl Schmitt irá publicar ao longo dos anos 20 e início dos 30. Nele, Schmitt já exibe atributos que iriam consagrá-lo como uma das principais figuras do cenário intelectual da Alemanha desse período: o tom polêmico; o estilo conciso, aparentemente simples da escrita; a originalidade, a ousadia na criação de conceitos; a erudição; a peculiar, e muitas vezes desorientadora, fusão de influências intelectuais do tradicionalismo político e religioso com uma aguda percepção da especificidade do mundo moderno; o pensar a partir do extremo.

Outros traços distintivos do "estilo intelectual" de Schmitt presentes no livro poderiam ser indicadas; prefiro, no entanto, deter-me por aqui e destacar o último ponto mencionado, pois acredito que ele ofereça uma porta de entrada para o texto sobre o "romantismo político". O livro, em certa medida, é um exercício de "história intelectual": analisa um tema da história das idéias políticas do século XIX, o romantismo político, tomando como ponto de partida uma tentativa de definição histórica e conceitual do movimento romântico. Ainda que essa caracterização não deixe de corresponder ao conteúdo do livro, ela é insuficiente. Esse mesmo exercício de história intelectual é também uma polêmica contra o romantismo e, em particular, contra o romantismo político. Uma polêmica que vê nesses dois movimentos a expressão de uma época, a época moderna, e que pretende pensar os fundamentos da ordem liberal-burguesa a partir de uma "situação limite", de um "caso extremo".

Essas duas perspectivas - a primeira mais propriamente histórica e a outra, digamos por ora, de caráter epocal - se cruzam e interpenetram ao longo do texto e, em última análise, se reúnem na maneira de 


\section{Bernardo Ferreira}

Schmitt abordar o romantismo. Segundo ele, a "estrutura do espírito romântico" ${ }^{4}$ deve ser considerada "no contexto da situação espiritual" (PR:62). Para tanto, seria preciso apreender o "centro" $(P R: 8,10)$ do romantismo, identificar sua "especificidade histórica" como "movimento espiritual" (PR:8). Aos olhos de Schmitt, isto significa "tomá-lo a sério, tanto do ponto de vista metafísico quanto moral, não como exemplo de uma tese abstrata, mas como uma realidade [Wirklichkeit] histórica concreta no contexto de um processo históri$\mathrm{CO}^{\prime \prime}(P R: 8)$.

Essa tentativa de evidenciar o "centro" do romantismo como "movimento espiritual" é própria da abordagem de Schmitt tanto da história intelectual quanto da vida política. Trata-se de tornar patentes as premissas últimas sobre as quais se funda uma ação, seja ela intelectual ou política, expondo seus pressupostos metafísicos. Por esse motivo, para Schmitt, a "explicação autêntica" do romantismo será aquela que for capaz de chegar à "fórmula metafísica" (PR:17) sobre a qual esse movimento estaria baseado. Nessa perspectiva, o privilégio concedido à "realidade histórica concreta" é mais, digamos, do que uma tentativa de reduzir o problema às suas variáveis sociológicas. Quando ele insiste na necessidade de se abordar o romantismo como uma "realidade histórica concreta no contexto de um processo histórico", o que está em jogo não é tanto a análise das determinações sociais desse movimento, mas uma tentativa de considerar sua "estrutura ideal" ${ }^{5}$ como um fator de conformação da experiência histórica. Trata-se, portanto, de reconhecer na "estrutura ideal" do romantismo as premissas metafísicas que organizam uma certa experiência histórica. Ao pretender determinar a "atitude perante o mundo" (PR:17) distintiva do romantismo, Schmitt tem em vista não só a sua inteligibilidade como fenômeno histórico, mas também seu significado como "manifestação na esfera do espírito" ( $P R: 3)$. Dessa forma, o exercício de história intelectual que ele nos propõe se desdobra em considerações sobre a natureza da Geistesgeschichte ("história do espírito") moderna. O privilégio concedido por Schmitt à "situação espiritual" como contexto de análise representa um esforço de caracterização histórica da "estrutura do espírito romântico" e, ao mesmo tempo, uma tentativa de apreender seu significado à luz da experiência moderna - em particular, como veremos, à luz da sua versão liberal-burguesa. Ou, caso se prefira, constitui uma forma de pensar a especificidade da "situação espiritual" do mundo moderno através da 
determinação da "estrutura e atitude metafísicas" (PR:19) que distinguem o movimento romântico.

Assim, para abordar o romantismo como uma "realidade histórica concreta", Schmitt retorna ao que, a seu ver, constituiria o começo da Geistesgeschichte moderna. Ele se volta para Descartes e busca no seu pensamento a cisão que distinguiria a experiência moderna do mundo $^{6}$. Para Schmitt, "duas grandes transformações" estariam associadas ao início da história intelectual moderna: com Copérnico, a Terra teria deixado de ser o centro do Universo; com a filosofia de Descartes, se iniciaria o "abalo do antigo pensamento ontológico" (PR:62). Isto porque

"[...] o seu argumento cogito ergo sum remeteu o homem para um processo subjetivo e interno, para o seu pensamento, em lugar da realidade [Realität] do mundo externo. A ciência natural deixou de ser geocêntrica e buscou o seu centro fora da Terra, o pensamento filosófico tornou-se egocêntrico e buscou o seu centro em si mesmo. A filosofia moderna é dominada por uma dissociação entre pensamento e ser, conceito e realidade, espírito e natureza, sujeito e objeto, que nem mesmo a solução transcendental de Kant remediou" (PR:62-63).

Schmitt não se detém sobre a natureza desse "antigo pensamento ontológico". E, como observa Luiz Costa Lima (1993:147-148), esse silêncio é revelador do seu alvo principal: ele demonstra muito mais preocupação em considerar os desdobramentos do "abalo" provocado pelo cogito cartesiano do que em caracterizar a realidade que o precedera. No entanto, essa antiga ontologia como que comparece em negativo no seu texto, seja pela insinuação daquilo que o mundo de Descartes já não é, seja por oposição àquilo que ele veio a ser. Nesse sentido, a julgar pelo que Schmitt afirma no trecho citado, o impacto destrutivo do cogito cartesiano sobre o "antigo pensamento ontológico" implicaria um duplo movimento: ele remete o homem para o seu próprio pensamento e, com isso, o dissocia de uma ordem externa da qual ele anteriormente se concebera como parte integrante. Dessa forma, o cogito cartesiano seria presa de uma espécie de círculo vicioso: ao mesmo tempo que rompe com a unidade homem-mundo precedente, procura superar a incerteza da experiência das coisas daí resultante, recompondo a realidade dessa experiência no próprio sujeito, no seu pensamento. Ao buscar o seu centro em si mesmo, o pensamento já não encontraria legitimidade no fato de ser coextensivo à or- 


\section{Bernardo Ferreira}

dem do mundo externo e seria obrigado a se defrontar com o problema da sua adequação ao próprio mundo. $\mathrm{O}$ "egocentrismo" da reflexão filosófica inaugurado por Descartes desembocaria, portanto, em uma "dualidade entre o conceito abstrato e o ser concreto" (PR:64). A dissociação entre pensamento e ser, conceito e realidade, espírito e natureza, sujeito e objeto, de que nos fala Carl Schmitt, decorreria do fato de que a própria substância das coisas já não se apresentaria como algo transparente para o entendimento humano. Assim, ao desligar-se do mundo e centrar-se no sujeito, a filosofia moderna viveria sob o signo de uma "recherche de la realitè"7.

Como já se pode entrever pelo que se disse anteriormente, essa "busca de um centro em si mesmo" que, segundo Carl Schmitt, marcaria o "egocentrismo" da filosofia na modernidade, traria consigo um outro resultado. O abalo da ontologia tradicional a que ele se refere não apenas remete o homem para dentro de si, "para um processo interno e subjetivo", como também esvazia a "realidade do mundo externo" da sua substância. A própria ordem do mundo torna-se um problema e, em última instância, pode ser vista como algo irracional ou inexplicável. Assim, os termos do que Schmitt chama de "problema filosófico da época" - ou seja, "a oposição entre pensamento e ser e a irracionalidade do real [des Realen]" transformação na "imagem teológica e metafísica do mundo". Mais especificamente, a busca da certeza da experiência das coisas no interior do próprio sujeito e o "egocentrismo" filosófico daí resultante têm um preço: eles custam à ontologia tradicional a perda da sua própria realidade. Se Descartes, como quer Schmitt, inaugura a "história intelectual" moderna, esse ato de fundação traz consigo uma questão que irá acompanhar a trajetória do "espírito moderno", qual seja, o de uma "realidade [Realität] inacessível ao racionalismo abstrato" $(P R: 64)^{10}$.

Schmitt, contudo, revela-se menos interessado nos termos da solução que Descartes oferece para essa questão - a certeza das idéias claras e distintas da matemática e a prova da existência de Deus na consciência de si mesmo - do que nos problemas suscitados pelo racionalismo cartesiano. Na verdade, ele não se aproxima desses temas na condição de filósofo ou sequer como um historiador da filosofia, mas como alguém interessado em retraçar algumas linhas de força da trajetória do "espírito moderno". Nesse sentido, Descartes é um ponto de partida e, ao mesmo tempo, um emblema das questões colocadas pela dis- 
solução das premissas da ontologia tradicional e pela emergência do sujeito no horizonte do pensamento moderno. Em outras palavras: mais do que uma "história intelectual", no sentido propriamente disciplinar de uma "história das idéias filosóficas", pode-se dizer que Schmitt tem em vista alguns desdobramentos daquilo que talvez caiba denominar de uma "história da razão moderna", e, em particular, o lugar central que nela ocupa a referência ao sujeito individual.

Portanto, a desestabilização dos fundamentos transcendentes da ordem está associada, na análise de Schmitt, à constituição do sujeito moderno. Ainda que nem sempre Schmitt o explicite para o seu leitor, a emergência do sujeito é um elemento central no seu argumento. Ela compõe uma espécie de figura de fundo, nem sempre evidente, mas cujo desenho, mais ou menos nítido, torna possível que outras figuras se destaquem. Permite pensar não só o "egocentrismo" da filosofia, como também o esvaziamento da "realidade" da ontologia tradicional e o conjunto de dissociações daí resultantes. Dessa forma, a emancipação do sujeito em relação a uma ordem externa das coisas se apresenta na sua exposição como um resultado e, ao mesmo tempo, um fator de desagregação da antiga "imagem teológica e metafísica do mundo".

Nesse sentido, a "recherche de la realitè" inaugurada pelo cogito cartesiano não se resumiria a uma mera "aspiração filosófica" ( $P R: 64)$ : seria reveladora de um impulso de fundamentação metafísica da experiência ao qual a modernidade tampouco teria escapado. Ela significaria a permanência de uma "atitude metafísica" para além da ruptura do elo que ligava o mundo humano ao seu fundamento transcendente. Nas palavras do próprio Schmitt,

“[...] a realidade [Realität] mais elevada e segura da antiga metafísica, o Deus transcendente, estava eliminada. Mais importante do que a controvérsia dos filósofos foi a pergunta por quem assumiu a sua função como a realidade [Realität] mais elevada e segura e, portanto, como o ponto último de legitimação na realidade [Wirklichkeit] histórica" (PR:68).

Portanto, ao procurar definir o romantismo através da "especificidade da sua situação espiritual" (PR:62), Schmitt realiza um duplo movimento. Por um lado, vai caracterizá-lo historicamente como uma das formas de reação ao racionalismo moderno; uma reação que, ao lado de contramovimentos do mesmo gênero, se distingue pelo seu caráter emocional-estético. Por outro, tentará estabelecer a "fórmula 


\section{Bernardo Ferreira}

metafísica" na qual se basearia o romantismo, apresentando-o como um ocasionalismo subjetivizado. Esquematicamente, pode-se dizer que esses dois níveis da análise de Schmitt correspondem às exigências que, como observei anteriormente, governariam a sua tentativa de determinação do "núcleo" do romantismo, ou seja: a sua inteligibilidade como tema da história intelectual e o seu significado como "manifestação na esfera do espírito". Na verdade, esses dois planos do argumento não estão separados: para Schmitt, o romantismo representa não apenas uma modalidade de reação ao racionalismo moderno, mas também um desdobramento e uma exacerbação dos dualismos inaugurados por este último. Romantismo e racionalismo deixam de ser vistos apenas como movimentos antagônicos e podem ser compreendidos também como realidades solidárias cujo sentido estaria associado a um mesmo processo histórico-espiritual. Este ponto se torna mais claro quando consideramos qual é, para Schmitt, a natureza da atitude romântica perante o mundo.

Segundo Schmitt, o racionalismo moderno teria suscitado diferentes contramovimentos que, por vias distintas, buscariam recompor a unidade da experiência ${ }^{11}$. Para ele, a peculiaridade do romantismo estaria no fato de que na sua reação ao racionalismo ele busca "transformar as oposições que vê em uma equilibrada harmonia estética. Em outras palavras, não conduz os dualismos a uma unidade, mas reduz as oposições a contrastes estéticos ou emocionais, para então fundi-los" (PR:65-66).

Para Schmitt, a "equilibrada harmonia estética" realizada pelo romantismo significa uma tentativa de dissolução daquilo que se apresenta como problema, transformando-o em um objeto de fruição estética pelo sujeito individual. A estetização romântica não resolve as oposições com que se defronta, simplesmente as suspende. Segundo ele, essa atitude constitui, em última análise, uma forma de evasão da realidade e dos seus constrangimentos. Ao se evadir da realidade e de seus limites, o sujeito romântico migra para a esfera do estético onde o mundo pode se tornar objeto de fruição pelo eu individual. Nesse âmbito, ele estaria em condições de desempenhar o "papel do eu criador do mundo" (PR:77), transformando a realidade como um todo no objeto de uma experiência subjetiva. Por essa razão, não se trata, para ele, de uma recusa da realidade em nome de alguma outra coisa, mas de um jogo com a realidade, um "ludus globi" (PR:111). O sujeito ro- 
mântico instrumentaliza o real e evita as suas imposições para fazer dele o material da sua própria fantasia.

Como observa Guy Oakes (1986:XX), Schmitt vê no romantismo uma espécie de "esteticismo ontológico". Nele, as coisas perdem toda e qualquer qualidade objetiva e existem apenas em função do interesse e da experiência estética que são capazes de suscitar. O mundo do romântico seria o mundo da lírica, onde a realidade somente adquire vigência como a mera projeção dos estados emocionais do indivíduo ${ }^{12}$. Com o romantismo, nos diz Schmitt, "o estético é absolutizado e alçado ao centro". Por outro lado, essa evasão para a esfera do estético traria consigo um outro resultado: "a estetização generalizada, considerada sociologicamente, serve apenas para também privatizar através do estético as outras esferas da vida espiritual" (PR:17). Assim, à rejeição da realidade objetiva do mundo provocada pela estetização generalizada corresponderia uma fragmentação da existência social resultante do processo de privatização.

O romantismo reagiria aos dualismos do racionalismo moderno conferindo validade absoluta a um dos pólos em que este teria dissociado o mundo: o sujeito. De certa forma, a atitude romântica consagra e radicaliza a emancipação do sujeito em relação à "realidade do mundo externo" iniciada pelo cogito cartesiano. Sob a forma de uma reação estético-emocional ao racionalismo moderno, o romantismo, na verdade, partilharia das mesmas premissas filosóficas e da mesma "estrutura ideal": tanto para um quanto para outro, o sujeito apresenta-se como o eixo a partir do qual se constrói a experiência da realida$\mathrm{de}^{13}$. Em última análise, o romantismo consumaria a tendência, inaugurada por Descartes, de buscar em um "processo subjetivo e interno" o fundamento último da experiência da realidade. Quando considerada à luz dos seus resultados extremos, essa tendência acabaria por suprimir todo fundamento objetivo da experiência. Tal seria o caso do romantismo. Daí a necessidade de isolar o seu núcleo central e colocar em evidência os desdobramentos lógicos da sua atitude perante o mundo. Assim, para Schmitt, a imagem de uma subjetividade auto-referida e do seu "ludus globi" revelaria seu caráter dissolvente se associada à idéia de occasio.

Segundo ele, a transformação do mundo em objeto de uma experiência individual - ou, o que não deixa de ser o mesmo, em uma realidade subjetiva -implica o abandono de toda regularidade objetiva das coi- 


\section{Bernardo Ferreira}

sas. A hipertrofia do sujeito tem como contrapartida o "esvaziamento da realidade do mundo [Entwirklichung der Welt]" (PR:85). A condição para o jogo romântico com a realidade e para a expansão dos caprichos solipsistas da imaginação estaria, portanto, na rejeição da idéia de causa. O mundo aos olhos do romântico se ofereceria como uma mera ocasião para o exercício da fantasia e para a realização de uma experiência estética. Tudo o que existe, repete Schmitt insistentemente, se transforma no "início de um romance infindável", em motivo de um "diálogo sociável" (PR:92), no qual o tema nada mais é do que um veículo para um "jogo de palavras" e para o prazer experimentado na conversação (cf. PR:92) ${ }^{14}$. Por isso, nos diz ele, a definição da natureza do romantismo não pode ser derivada dos objetos para os quais se dirige a produtividade estética do sujeito individual. Em última análise, o que desperta o seu interesse "reside de tal forma no subjetivo, naquilo que o eu romântico por si só acrescenta, que, a rigor, não se pode mais falar de objeto ou coisa, porque o objeto se torna puro 'pretexto', 'começo', 'ponto elástico', 'incitação', veículo' ou como quer que soem as paráfrases [Umschreibung] da occasio nos românticos" (PR:93).

O fator determinante para uma caracterização do romantismo se encontraria, segundo Schmitt, na atitude do sujeito diante do mundo, na sujeição de todos os objetos às exigências do seu interesse estético. A "poetização" romântica ignora o conceito de causa, pois "tudo que dá à vida e aos acontecimentos coerência e ordem [...] é incompatível com a imagem do mero ocasional" ( $P R: 18)$. Com isso, a fuga da realidade mostra-se infensa a toda regularidade normativa e a todo posicionamento ou julgamento efetivo. O romântico, nos diz Schmitt, é incapaz, em última análise, de qualquer decisão política ou juízo moral, pois isto lhe exigiria renunciar à sua "reserva subjetiva" (PR:83) e ceder aos imperativos do real. Um dos traços distintivos do romantismo estaria na sua ironia. A ironia romântica não se restringe, no livro Romantismo Político, a um simples recurso de expressão artística, mas possui um significado claramente metafísico. Ela seria uma manifestação da atitude romântica perante o mundo, uma forma de preservação de uma distância em relação à realidade. A ironia é "o instrumento intelectual do sujeito que mantém a sua reserva em relação à objetividade" $(P R: 82)^{15}$. Com isso, o indivíduo romântico conservaria em relação à efetividade limitada do real uma infinidade de possibilidades subjetivas. 
Assim, a maneira pela qual o romantismo encara o mundo, como algo absolutamente disponível, permitiria defini-lo como uma espécie de ocasionalismo. Schmitt toma essa caracterização da filosofia de autores como Geraud de Cordemoy, Geulincx, Malebranche que teriam procurado resolver os dualismos do pensamento cartesiano buscando em Deus a verdadeira causa de todas as coisas. Em lugar da cisão entre corpo e alma, entre res extensa e res cogitans, haveria um "terceiro fator abrangente [umfassendes Drittes]" (PR:96) no qual essas divisões revelariam seu caráter ilusório. $\mathrm{O}$ mundo dos ocasionalistas torna-se, observa Schmitt, um mundo sem consistência própria, já que aos olhos de Deus ele é uma mera ocasião para a realização da sua vontade. No entanto, o fato de Deus permanecer como causa primordial e unidade superior impediria que esses efeitos dissolventes se atualizassem. Sua força desintegradora seria anulada pela preservação da divindade como princípio objetivo.

O mesmo já não ocorreria com o romantismo. Ele conservaria a atitude ocasionalista, eliminando o fundamento objetivo sobre o qual, em última análise, aquela teria se baseado. Ou melhor, o romantismo como que multiplicaria indefinidamente a figura de Deus do antigo ocasionalismo, colocando no seu lugar o sujeito individual. Enfim, no romantismo, o ocasionalismo acabaria por ser subjetivizado: "a especificidade do ocasionalismo romântico está em que ele subjetiviza o principal fator dos sistemas ocasionalistas: Deus. No mundo burguês e liberal, o indivíduo desvinculado, isolado e emancipado torna-se o centro, a instância última, o absoluto" $(P R: 105)^{16}$.

Gostaria de me deter sobre essa questão, pois ela permite reunir diversas pontas do meu argumento que até agora estiveram soltas. Através da descrição do romantismo como um ocasionalismo subjetivi$z a d o$, Schmitt apresenta a imagem de um mundo em que o sujeito individual se torna o "ponto último de legitimação". Daí a importância da sua referência ao "indivíduo isolado do mundo liberal burguês". Esta não deve ser entendida apenas como uma forma de explicitação das condições sociológicas da atitude romântica. Na verdade, esse tipo de sociologia do conhecimento não é estranho a Schmitt, como ele mesmo observa no prefácio de 1924 à segunda edição do livro, "o portador do movimento romântico é a nova burguesia" (PR:14). Entretanto, acredito que essa conexão entre ocasionalismo romântico e ordem liberal-burguesa ganha em significado quando nos lembramos que, ao definir o romantismo pela idéia de occasio, Schmitt pretende pôr 


\section{Bernardo Ferreira}

em evidência a "fórmula metafísica" capaz de qualificar a natureza da atitude romântica perante o mundo. E não só: ele quer ponderar sobre o seu significado como "manifestação na esfera do espírito" e, portanto, como expressão da Geistesgeschichte moderna. Ora, se faz sentido a interpretação que até agora procurei sustentar, Schmitt oferece-nos uma imagem dessa "história do espírito" em que a emancipação do sujeito em relação à "realidade do mundo externo" é uma das linhas de força dominantes. Ao centrar-se em si mesmo, o sujeito moderno torna problemática a própria ordem do mundo que fora consagrada pela antiga ontologia. O romantismo, tal como Schmitt o analisa, inverte os termos da questão: ele é uma tentativa de fundamentar a ordem no próprio sujeito. E, nesse sentido, realiza um movimento análogo ao da promoção do indivíduo no mundo burguês. A ordem burguesa, observa Schmitt, "isola o indivíduo na esfera do espírito, o remete para si mesmo e lhe atribui o conjunto da carga que outrora estava distribuída hierarquicamente por diferentes funções em uma ordem social" (PR:20).

Essa analogia, insisto, não se esgota em uma sociologia do conhecimento, mas pretende tornar manifesta a correspondência entre a estrutura conceptual última do romantismo e a do mundo burguês ${ }^{17}$. Formulado em outros termos, o ocasionalismo romântico é uma representação radicalizada da privatização da experiência levada a cabo na ordem liberal-burguesa. Ambos são tributários de uma metafísica do sujeito que se sustenta na imagem do indivíduo que encontra o seu centro em si mesmo. Da mesma forma que na sociedade burguesa o indivíduo vem a ser "o seu próprio sacerdote", o romantismo tem "no sacerdócio privado" a sua "raiz última" (PR:20-21). Para Schmitt, a situação-limite da afirmação dessa subjetividade auto-referida e autárquica está na subjetivização do próprio princípio da ordem. O ocasionalismo romântico pode ser visto como o caso extremo dessa metafísica do sujeito. Nele, o princípio de ordem transforma-se em fator de fragmentação e dispersão.

Assim, o mundo que Schmitt deduz da atitude romântica perante a realidade - seria possível dizer que Schmitt deriva como resultado último da moderna metafísica do sujeito - é um mundo onde a ordem se tornou um problema, um mundo sem fundamento objetivo. Através da privatização, "se dissolve a hierarquia da esfera do espírito" (PR:17) e uma estrutura social hierárquica e tradicional transforma-se em uma "sociedade dissolvida individualisticamente" 
(PR:20). Como afirmei há pouco, a imagem que Schmitt nos apresenta do romantismo leva ao extremo e dramatiza esse processo de dissolução de uma ordem objetiva das coisas. A hipertrofia do sujeito individual anula toda e qualquer regularidade do mundo externo (a Entwirklichung der Welt à qual me referi anteriormente). A transformação da realidade em uma ocasião para o exercício da fantasia individual, a estetização generalizada fazem com que "toda norma apare[ça] como tirania anti-romântica" (PR:126). O mundo do romantismo não conhece "nem distinções lógicas, nem juízos morais de valor, nem decisões políticas" (PR:130). Paradoxalmente, a hiperatividade subjetiva desemboca em uma postura passiva ${ }^{18}$. Para Schmitt, a elevação do indivíduo a "ponto último de legitimação na realidade histórica" conduz à diluição de todo princípio objetivo da ordem e, finalmente, à impotência epistemológica, ao niilismo moral e ao imobilismo político. O ocasionalismo romântico e o seu movimento de "secularização de Deus no sujeito genial" ( $P R: 165)$ seriam a expressão mais acabada dessas tendências.

Com a secularização de Deus no indivíduo, o romantismo levaria às últimas conseqüências uma atitude metafísica que, longe de dar alguma consistência ao mundo, lhe subtrai todo fundamento objetivo. $\mathrm{Na}$ metafísica do sujeito consagrada pelo romantismo, a estrutura metafísica de pensamento e a necessidade de remeter a ordem a um fundamento último seriam "preenchidas" por um princípio, o sujeito individual, incapaz de assegurar algum tipo de estabilidade ao mundo. Para Carl Schmitt, a metafísica do sujeito sustenta-se sobre uma ilusão: ela eleva a princípio último da ordem um fator que no final das contas a inviabiliza. Como ele próprio observa, "o sujeito genial, quando levou a sério a sua autarquia divina, não tolerou mais uma comunidade" (PR:75). Imerso na sua condição de Deus secular, o sujeito moderno instrumentaliza o mundo sem, no entanto, lhe conferir coerência interna. A metafísica sobre a qual se ergue a ordem liberal-burguesa transforma a vida social em algo de contingente e precário não só porque subjetiviza a instância última, pulverizando-a e multiplicando-a, mas também porque se ilude ao acreditar na possibilidade de uma ordem resultante da autonomia do sujeito individual. Disso redunda, nos diz Schmitt, "um mundo ocasional, um mundo sem substância e sem vínculo funcional, sem direção fixa, sem conclusão e sem definição, sem decisão, sem tribunal último, que segue adi- 


\section{Bernardo Ferreira}

ante interminavelmente, guiado apenas pela mão mágica do acaso, the magic hand of chance" (PR:19-20).

O romantismo se apresentaria, portanto, como uma renúncia radical à própria possibilidade de uma ontologia. Na modernidade, segundo Schmitt, a História e a Humanidade, nas suas diferentes figuras, teriam se apresentado como princípios de uma "nova ontologia", como os "novos demiurgos" de uma ordem puramente secular. Em ambos os casos, tratava-se de princípios "objetivos e evidentes na sua validade supra-individual" ( $P R: 68)$, para os quais se pretendia reivindicar o lugar ocupado por Deus na metafísica tradicional. Com a entronização romântica do eu, o que se elimina é justamente esse ponto de referência objetivo e supra-individual e, dessa forma, deixaria de fazer sentido a idéia de uma ontologia, ainda que uma ontologia secular. Portanto, o romantismo, insisto, levaria às suas últimas conseqüências a dissolução dos fundamentos tradicionais da ordem - ou, para utilizar os termos do próprio Schmitt, a desagregação da "hierarquia da esfera do espírito". Ele realizaria em toda a sua extensão uma possibilidade contida na própria "imagem metafísica do mundo" inaugurada pela modernidade. No mundo romântico, a realidade se vê despojada do seu arcabouço ontológico; trata-se de um mundo que não possui forma própria, já que a produtividade do sujeito individual não seria capaz de conferir qualquer regularidade e direção à experiência concreta.

Essa incapacidade de dar forma à realidade se traduziria no caráter problemático que a própria arte tenderia a assumir no romantismo. Para Schmitt, a natureza dissolvente da estetização romântica tem, em última análise, um caráter autofágico, ela absolutiza a arte e, com isso, acaba por tornar problemática a própria expressão artística. No romantismo, todas a formas artísticas se convertem em mero pretexto para as expansões da subjetividade e, com isso, a criação estética "tem que se distanciar de toda forma, assim como da realidade concreta" (PR:20). O caráter ocasional da arte romântica se evidenciaria na impermanência e no vazio das suas formas, já que estas seriam, acima de tudo, um meio de expressão da fantasia subjetiva. Em lugar de assegurarem algum tipo de fixação da experiência, as formas se tornariam elas mesmas um "veículo" a serviço da instrumentalização da realidade pelos caprichos da imaginação individual. O romantismo, nos diz Schmitt, a propria-se de formas das mais diferentes épocas, sem jamais consolidar uma forma própria. Esse processo de "romantização 
das formas alheias" (PR:15) seria característico da dissolução dos conteúdos objetivos da realidade resultante da primazia do sujeito individual. Ao se dobrar às exigências expressivas de um eu desligado de todo vínculo normativo, a arte romântica só conheceria "formas sem substância [que] se deixam relacionar a qualquer conteúdo" (PR:86-87). A arte romântica, nessa perspectiva, seria "uma arte sem publicidade e sem representação [Repräsentation]" (PR:16). No entanto, para Schmitt, este não é um traço exclusivo da arte romântica. O romantismo, nesse ponto, é um exemplo - certamente um exemplo extremo - de uma "situação espiritual" mais abrangente, que diz respeito às premissas últimas sobre as quais se funda a própria modernidade. Segundo Schmitt, o romantismo "é, como um todo, a expressão de uma época que, na arte assim como em outras esferas do espírito, não introduziu nenhum grande estilo e que, em um sentido preciso, não é mais capaz de representação [Repräsentation]" (PR:16).

Permanece em aberto o conteúdo mais exato da idéia de "representação" nesse trecho. Para tanto, seria preciso acompanhar a análise de Schmitt sobre o conceito de Repräsentation no livro Römischer Katholizismus und politische Form (Catolicismo Romano e Forma Politica) ${ }^{19}$. Para efeito deste trabalho, é suficiente indicar que essa crítica à incapacidade de representação não se restringe ao terreno da discussão estética. A despeito de uma certa nostalgia que atravessa o texto de Schmitt, não me parece estar em jogo aqui apenas a defesa de uma idéia tradicional de representação como reflexo ou a simples tentativa de restaurar uma concepção substancialista de ordem ${ }^{20}$. Para ele, a perda de capacidade representativa está diretamente associada à renúncia a uma dimensão normativa. Em última análise, o romantismo e, por conseguinte, a ordem liberal-burguesa e a própria época moderna não estariam em condições de dar forma e direção à realidade humana. Assim, por meio da polêmica contra o romantismo, a crítica de Schmitt aos princípios da ordem liberal-burguesa reúne-se a uma crítica da modernidade. A rigor, as duas perspectivas não estão separadas. Não custa insistir: ao buscar definir a "fórmula metafísica" sobre a qual se baseia o romantismo, Schmitt tem em vista, ao mesmo tempo, a "imagem metafísica" da época moderna. Em última análise, o romantismo, a ordem liberal-burguesa, a modernidade são tributários da mesma "estrutura ideal" e participam da mesma "situação espiritual". 


\section{Bernardo Ferreira}

Entretanto, para Schmitt, a sustentação da imagem de uma ordem fundada na autarquia do indivíduo tem limites precisos. Ela pressupõe a existência de um estado de coisas, de uma situação concreta em que seria possível sustentar a crença no caráter naturalmente positivo da produtividade do sujeito individual; uma situação, portanto, em que os efeitos dissolventes dessa produtividade poderiam ser ignorados. Não é por outra razão que Schmitt insistirá na idéia de que "o romantismo é psicológica e historicamente um produto da segurança burguesa" (PR:107). Da segurança burguesa teria se alimentado uma atitude perante o mundo baseada na crença no "sacerdócio privado" como base da existência coletiva. Contudo, observa Carl Schmitt em uma chave nitidamente polêmica, essa já não seria a realidade do século XX: "durante o século XIX se realizou de forma ininterrupta e com grande rapidez a dissolução da antiga sociedade em direção à atual democracia de massas, por meio da qual foram eliminadas precisamente toda dominação da burguesia liberal e sua cultura [Bildung]" (PR:15).

A impossibilidade de sustentar a ilusão que a ordem liberal-burguesa construiu a respeito de si mesma nos conduz a uma última questão: a crítica de Carl Schmitt à inoperância política do romantismo. Neste ponto se concentra grande parte da energia polêmica do seu livro. Em uma realidade que já não é mais a da "segurança burguesa", não só a imagem de mundo a ela associada se demonstraria finalmente insustentável, como também os seus perigos inerentes seriam potencializados. Com isso, a insistência de Schmitt na nulidade política do romantismo deve ser considerada em função de uma estratégia que pretende avaliar, à luz de uma perspectiva-limite, os desdobramentos da metafísica romântica. A identificação do ocasionalismo subjetivizado como o "centro" do romantismo é indissociável do seu juízo sobre a política romântica, pois é através do reconhecimento desse núcleo metafísico que Schmitt irá derivar e deduzir suas conseqüências práticas e políticas. A impotência política do romantismo é, em última análise, resultado da sua própria atitude perante o mundo. Dessa forma, a busca de uma "explicação autêntica" não se distingue, para Schmitt, de um parti pris, no sentido mais literal da expressão; pelo contrário, é até mesmo condicionada por ele.

Para Schmitt, quando transposta para a vida política, a atitude romântica resultaria em uma paralisia da ação. Por isso, insiste ele, "onde se inicia a atividade política se encerra o romantismo político" 
(PR:165). O fato de este último estar baseado na produtividade estética do sujeito individual anula seu significado prático. Recusando os imperativos do real em nome do jogo da fantasia, o romântico subtrai-se a toda posição para preservar sua autarquia subjetiva. A estetização romântica revelaria seu caráter dissolvente no distanciamento irônico do sujeito em relação à efetividade do real, na suspensão do juízo e no abandono da ação; o indivíduo como que se torna um simples espectador da realidade. Nesse contexto, de acordo com Schmitt,

"[...] nem decisões religiosas, nem morais, nem políticas, nem conceitos científicos são possíveis no domínio do puramente-estético. Todavia, todas as contraposições e distinções objetivas [sachlichen], bom e mau, amigo e inimigo, Cristo e Anticristo, talvez possam se tornar contrastes estéticos e meios da trama de um romance e se acomodar esteticamente no efeito global de uma obra de arte" (PR:17).

O imobilismo, a postura passiva e, por fim, a incapacidade de decisão seriam a contrapartida no campo da vida prática dos efeitos dissolventes do ocasionalismo romântico. Para o romantismo político, a realidade política nada mais é do que uma mera ocasião para a produtividade subjetiva. A eliminação dos pontos de referência objetivos e a instrumentalização da realidade corresponderiam à renúncia antecipada a toda e qualquer intervenção no mundo. Por isso, em uma de suas afirmações caracteristicamente axiomáticas, Schmitt considera que "o romantismo político é uma emoção de acompanhamento [Begleitaffekt] do romântico para um acontecimento político" (PR:166). Dessa maneira, Schmitt apresenta-nos um quadro em que a indefinição política do romantismo se acrescenta à indefinição ontológica resultante da sua atitude perante o mundo.

Portanto, ao se propor como teoria política, o romantismo não iria além de "uma espécie de paráfrase [Umschreibung] lírica da experiência" (PR:165). Na sua rejeição a todo posicionamento substantivo, acabaria por se combinar com as mais diferentes posições políticas, sem aderir a nenhuma delas. Essa combinação indiscriminada com diversas perspectivas políticas seria resultado da sua própria natureza ocasional. O romantismo, na análise de Schmitt, não possui conteúdo próprio, pois a condição da liberdade sem limites do sujeito individual estaria no seu desligamento de toda substância objetiva e de toda posição determinada. Nesse sentido, "não existem idéias românticas, mas apenas idéias romantizadas" (PR:149). Em última ins- 


\section{Bernardo Ferreira}

tância, a atividade de estetização conduz a um envolvimento puramente formal com os seus objetos. Daí, a adaptabilidade do romantismo aos mais diferentes conteúdos políticos. As formas vazias da experiência estética constituiriam para o sujeito romântico a única "moldura" da sua independência individual. Ao instrumentalizar a realidade em função do seu próprio deleite estético, ao se relacionar com o mundo de maneira exclusivamente formal, o sujeito romântico se recusaria a colocar a questão dos fins, ele seria incapaz de oferecer uma direção à sua própria experiência. Todavia, observa Schmitt, por ser incapaz de um posicionamento substantivo, o romantismo ficaria à mercê das decisões políticas de forças alheias (cf. PR:168).

Assim, para Schmitt, a suposta superioridade do gênio romântico se mostraria a um olhar mais atento como impotência. Com efeito, nos diz ele, "a raiz da sublimidade [Erhabenheit] romântica é a incapacidade de decisão" (PR:120). Isso lhe permite configurar uma situação em que a carência de fundamento do mundo não encontra nenhum tipo de contrapartida. Pelo contrário, na atividade autocentrada do sujeito romântico se verificaria a renúncia a regras e valores comuns, a dissolução de todo princípio normativo sobre o qual fundar uma ordem:

“[...] uma emoção que não ultrapassa a esfera do subjetivo não pode fundar nenhuma comunidade, a embriaguez da sociabilidade não é base de um vínculo duradouro, ironia e intriga não são pontos de cristalização social e não se pode erguer uma ordem social sobre a necessidade de não estar sozinho, mas de pairar na agitação de uma conversação animada. Porque nenhuma sociedade pode encontrar uma ordem sem um conceito do que é normal e do que é Direito [Recht]. O normal é, por definição, não-romântico, porque toda norma destrói a independência ocasional do romântico" (PR:167).

Para Schmitt, o processo de emancipação do sujeito em face dos pressupostos da ontologia tradicional não só desestabiliza a possibilidade de uma fundamentação substancial dos princípios normativos, como implica a renúncia da própria idéia de uma ordem normativa. Expressão extrema daquele processo, o romantismo não teria como oferecer uma contrapartida política para a dissolução individualista da "hierarquia da esfera do espírito". Assim, sua nulidade política não se distingue da sua impotência normativa. Se o sujeito romântico, como repete Schmitt insistentemente, não é capaz de nenhuma decisão, é porque ele não admite se sujeitar a um posicionamento norma- 
tivo diante da realidade. A incapacidade romântica de decisão seria, em última análise, a incapacidade de estabelecer uma ordem fundada em parâmetros de normalidade partilhados e minimamente estáveis.

\section{O SUJEITO DA ORDEM}

"Disse-lhe Pilatos: 'Que é a verdade'?" João 18,38

O problema da norma e da ordem, ou, caso se prefira, a questão de uma ordem normativa, também ocupa um lugar central em dois livros publicados por Schmitt no início dos anos 20. Refiro-me a Die Diktatur (A Ditadura), de 1921, e Politische Theologie (Teologia Política), de 1922. Muito próximos entre si, ambos podem ser interpretados como um contraponto, no terreno da reflexão jurídico-política, a alguns dos problemas colocados pela análise do romantismo político no campo da história das idéias e da crítica cultural. Não pretendo expor separadamente, como fiz com Politische Romantik, cada um dos textos. Gostaria de considerá-los em conjunto, a partir do seu confronto com alguns dos eixos centrais da discussão sobre o romantismo. Nesse sentido, interessa-me considerar em que medida a discussão sobre o fundamento de uma ordem normativa nesses dois livros pode ser pensada à luz de três questões centrais da crítica de Schmitt ao pensamento romântico. Mais especificamente: a recusa do real, a renúncia à decisão e a relação entre sujeito e ordem.

Tomemos como ponto de partida um trecho extraído do livro Legalität und Legitimität (Legalidade e Legitimidade), de 1932: "nenhuma norma [...] se interpreta ou se aplica, se protege ou se defende a si mesma; nenhuma validade normativa se faz valer a si mesma; e também não existe - caso não queiramos nos estender em metáforas e alegorias nenhuma hierarquia de normas, apenas hierarquias de homens e de instâncias concretas" (LL:53).

Este trecho é, sob diversos aspectos, exemplar, seja pela insistência com que Schmitt faz afirmações semelhantes em diferentes momentos da sua obra ${ }^{21}$, seja porque, em alguma medida, sintetiza em uma fórmula sua crítica ao problema do fundamento de uma ordem normativa. Para Schmitt, como se pode ver, o fundamento de validade de um sistema normativo não é jamais algo evidente em si mesmo. Em última análise, nenhuma norma contém em si o princípio da sua pró- 


\section{Bernardo Ferreira}

pria validade. Mais ainda: não haveria como derivar a validade de uma ordem normativa de uma suposta universalidade ou racionalidade dos seus conteúdos. Para que isto fosse possível, seria necessário pressupor a existência no interior da vida social de um quadro de valores incontroverso, de algum tipo de consenso normativo. $\mathrm{Na}$ ausência deste, seria preciso instituir as condições factuais em que as normas pudessem ter vigência, ou seja, em que a sua validade viesse a ser "universalmente" reconhecida. Nesse caso, porém, a universalidade de semelhante reconhecimento já não seria uma decorrência da natureza em si mesma universal e incontestável dos princípios normativos, mas o resultado da criação de um "meio homogêneo" (D:133; PT:19). A impossibilidade de um consenso fundado em critérios universais e objetivos traria consigo a exigência de uma instância de validação da norma. Noções como "bem comum", "justiça", "paz", "ordem pública", "liberdade", na medida em que carecem de um sentido unívoco e socialmente partilhado, não se tornam efetivas sem que uma interpretação específica se imponha. Elas precisam se revestir de um significado concreto para ter algum tipo de validade ${ }^{22}$. Se um imperativo moral ou jurídico precisa ser interpretado para ganhar efetividade, se a sua validade não está automaticamente dada por seu conteúdo, se é necessário criar as condições da sua vigência, a questão, para Schmitt, transfere-se do plano de um juízo ético ou jurídico - incondicionado e puramente normativo - para o plano do conflito político.

Para Carl Schmitt, a impossibilidade de um conteúdo normativo se tornar efetivo por si mesmo se revelaria em toda a sua amplitude à luz do tema da exceção. Em uma situação anormal, seria possível reconhecer as condições de validade de uma norma. Segundo ele, essa validade não é, como uma perspectiva racionalista gostaria de crer, incondicional: a norma não pode valer em uma situação de exceção, ou seja, em uma situação fora da norma, na qual, por princípio, ela não se aplica. Dessa forma, observa Schmitt,

“[...] quem parte da idéia de estar em presença de uma situação anormal - ou porque contempla o mundo em um estado de anormalidade radical, ou porque apenas considera uma dada situação como anormal - resolverá o problema da política, da moral e do direito de forma distinta de quem está convencido da sua normalidade de princípio, somente transtornada por pequenas perturbações" ${ }^{23}$. 
O ponto de vista da "normalidade de princípio" seria incapaz de resolver a questão do fundamento de validade de uma norma, pois tomaria a própria situação normal como algo antecipadamente garantido, ou seja, conceberia as condições em que uma norma é válida como previamente dadas. No entanto, pensa Schmitt, "toda norma geral exige uma configuração [Gestaltung] normal das relações de vida" (PT:19). Em face da perspectiva do estado de exceção, diante da possibilidade de uma situação concreta em que a validade de um sistema normativo é necessariamente suspensa, seria preciso admitir que a "normalidade factual [faktische]" não é apenas um "pressuposto externo", mas sim algo que diz respeito à "validade imanente" $(P T: 19)^{24}$ de uma norma. Nessa perspectiva, afirma Schmitt categoricamente, "todo direito é 'direito situacional' [Situationsrecht]" (PT:19). A vigência de um sistema normativo precisaria ser concebida em termos das condições concretas em que uma proposição é publicamente reconhecida como norma. Com isso, a reflexão jurídica de Schmitt abre-se, necessariamente, para uma consideração da realidade histórica e política, sem que isto signifique, para ele, uma simples redução do direito aos seus condicionamentos concretos. Pelo contrário, como espero fique claro na seqüência da minha exposição, ele procura pensar as condições do governo normativo da realidade a partir da situação-limite em que a aniquilação do direito se confunde com a sua própria criação. Daí a importância de se considerar a realidade a partir do "caso-limite [Grenzfall]" de uma situação anormal - em que a suspensão das normas e da normalidade colocaria o problema da sua própria instauração -, e não a partir do "caso normal" (PT:13) - em que a vigência das normas se faria enganosa. A aparente naturalidade daquilo que é tido como normal seria apenas fruto de "generalizações de algo que se repete de forma ordinária [des durchschnittlich sich Wiederholenden]" (PT:21). Uma vez que a norma não se apresenta como evidente em si mesma e capaz de se auto-instituir, dada a impossibilidade de pressupor um consenso em torno de princípios normativos, a questão passa a estar nas condições de instauração da normalidade.

Assim, o problema da normalidade e o conceito de "normal", em Schmitt, não se definem em termos normativos, mas acima de tudo políticos ${ }^{25}$. A estabilidade e a normalidade de uma dada situação não podem ser concebidas in abstracto, elas dependem, em última análise, da definição de uma "hierarquia de homens e instâncias concretas". 


\section{Bernardo Ferreira}

Portanto, a questão da validade de uma ordem normativa não se resolve em função do conteúdo das normas, mas, nas suas próprias palavras, "é preciso criar um ordenamento [Ordnung] para que o ordenamento jurídico [Rechtsordnung] tenha um sentido" (PT:19) ${ }^{26}$. Com isso, norma jurídica e ordem política vêm a ser conceptualmente separadas, ao mesmo tempo que se estabelece uma dependência estreita entre as regras do direito e uma "configuração normal das relações de vida". Como Schmitt observará mais adiante na sua Verfassungslehre (Teoria da Constituição), de 1928, a validade do dever-ser do direito não pode ser dissociada do ser político concreto que, em última análise, constitui "o essencialmente existencial [das wesentlich Existenzielle] desse fundamento de validade" (VL:76, ênfases no original). Dessa forma, ele procura afirmar a primazia das relações políticas em face da vigência das normas do direito e insiste na idéia de que a existência de unidade política constitui o pressuposto da validade e da unidade do próprio ordenamento jurídico. Nesse contexto, a constituição de uma situação normal implica a exclusão das situações alternativas:

"[...] a unidade política é a unidade suprema, mas não porque dita todo-poderosa ou porque nivela todas as demais unidades, mas porque decide e pode impedir que, no seu interior, todos os outros agrupamentos antagônicos se dissociem até a extrema inimizade (ou seja, a guerra civil). Lá onde ela está presente, os conflitos sociais dos indivíduos e grupos sociais podem ser decididos, de forma que existe uma ordem, ou seja, uma situação normal. Ou a unidade mais intensa está presente ou não está; ela pode se dissolver, então a situação normal deixa de existir. Mas inevitavelmente ela é sempre unidade, porque não existe pluralidade de situações normais" ${ }^{27}$.

Contudo, a insistência na primazia da existência política sobre o ordenamento jurídico não significa uma recusa da dimensão normativa e o simples reconhecimento da prioridade das relações de força e de poder sobre o direito. Na verdade, trata-se, por um lado, de afirmar a impossibilidade de esgotar o direito na imanência do sistema de legalidade. Por outro, está em jogo a possibilidade do estabelecimento de uma ordem normativa dotada de efetividade. Para Schmitt, a insistência no tema da exceção está diretamente associada ao tema da "realização do direito" [Rechtsverwirklichung $]^{28}$. O que ele rejeita, portanto, é a generalidade abstrata de uma norma contida em si mesma e desligada de toda situação concreta. Com efeito, nos diz ele, em um 
texto de 1934: "a norma ou a regra não cria a ordem; em vez disso, ela tem apenas, com base numa dada ordem e no interior dela, uma certa função reguladora, cuja validade é, em uma medida relativamente restrita, autônoma e independente da situação das coisas" (DarD:11).

Para que uma norma possa assumir um caráter geral e se elevar para além das circunstâncias particulares a serem reguladas, é preciso introduzir algum grau de calculabilidade e regularidade na própria situação que ela pretende governar. Com isso, o problema transfere-se da generalidade da norma para a relativa estabilidade da situação concreta (cf. D:163). Uma norma geral, reconhece Schmitt, tem que possuir uma certa dose de independência em relação aos casos particulares; trata-se de uma premissa da sua própria validade. Todavia ela não pode se elevar demasiadamente acima do estado de coisas específico que tem por tarefa dirigir. Sua autonomia é restrita, pois, em última análise, "a regra segue a situação mutante para a qual foi definida" (DarD:20, ênfase no original).

Nada mais característico dessa imagem de dependência da esfera normativa em relação à realidade concreta do que a análise de Schmitt sobre o conceito de ditadura. A ditadura, para ele, não se confunde com o despotismo, já que os poderes extraordinários exercidos pelo ditador têm como objetivo criar as condições concretas para que o direito possa ter vigência. Em última análise, a ditadura visa à sua própria supressão. Ela envolve uma ação orientada para a realização de um fim específico e a obtenção de um resultado concreto: a eliminação dos obstáculos à efetivação do direito na vida social. No entanto, observa Schmitt, a natureza de tais impedimentos não pode ser definida antecipadamente, não há como regulamentá-la. Tal fato impediria, por sua vez, a delimitação jurídica precisa do conteúdo dos poderes ditatoriais. Nesse sentido, a ditadura apresenta-se, em Schmitt, como uma "comissão de ação determinada pela situação das coisas [Sachlage]" (D:134). Justamente por estarem "determinadas pela situação das coisas", a competência e a esfera de ação do ditador seriam incondicionadas, ou seja, se definiriam essencialmente de forma concreta, tendo em vista os fatos a serem enfrentados. Os recursos de poder e os meios necessários para a consecução dessa tarefa dependeriam da sua própria deliberação, de uma avaliação das circunstâncias e do reconhecimento da necessidade de estabelecer "exceções de acordo com a situação das coisas" ( $D: 38)$. Dessa forma, a ditadura é pensada em Schmitt como um instituto do direito público cujo conteúdo, al- 


\section{Bernardo Ferreira}

cance e competência não podem, em última análise, ser delimitados juridicamente. Com efeito, observa Schmitt, o "conteúdo preciso" da ação ditatorial depende da

"[...] noção de um adversário concreto, cuja eliminação deve ser o que há de mais próximo de uma delimitação do objetivo da ação [das nächstumschribene Ziel der Aktion]. A delimitação [Umschreibung] de que se trata aqui não é uma apreensão dos fatos através dos conceitos do direito, mas uma determinação puramente factual [ist keine tatbestandmäßige Erfassung durch Rechtsbegriffe, sondern eine rein tatsächliche Präzisierung]" (D:132).

A questão da ditadura traria consigo o reconhecimento da impossibilidade de conter o conjunto da realidade no interior de um sistema normativo. Na ação do ditador, segundo Schmitt, o respeito às normas do direito precisa ser suspenso para que se criem as condições factuais de validade do próprio direito. Trata-se de uma ação, portanto, que encontra a sua referência imediata na realidade concreta e que extrai os seus critérios da própria "situação das coisas". Ao contrário do que se observaria em um quadro de normalidade, no qual se poderia pressupor que os fatos seriam governados pelas normas do direito, na ditadura, os fatos determinariam os rumos da conduta da autoridade pública. Nessa perspectiva, observa Schmitt, "se justifica tudo que é necessário do ponto de vista do resultado concreto a ser alcançado" (D:XVIII). Com isso, a ditadura reveste-se, a seu ver, de um caráter claramente técnico, ela se apresentaria como um meio para alcançar um fim específico ${ }^{29}$. Em última análise, o que torna a comissão do ditador incondicionada do ponto de vista das normas do direito é o seu condicionamento pela "imediata atualidade de uma situação a ser eliminada" ( $D: 133)$. Todavia, é preciso insistir, o reconhecimento das determinações factuais da ditadura e, portanto, do arbítrio pessoal inerente aos poderes extraordinários do ditador não significa uma simples defesa da arbitrariedade. Como já observei anteriormente, a análise de Schmitt parte da idéia de que a racionalidade de uma ordem normativa não se resolve em si mesma, mas exige para a sua própria efetivação a consideração de um elemento que, por assim dizer, lhe é "estranho", um dado "irracional". Portanto, não está em jogo aqui a exaltação irracionalista do "concreto" e da "atualidade imediata", mas a tentativa de estabelecer uma relação entre o abstrato e o concreto, entre o dever-ser da norma e o ser da realidade. Essa relação, em Schmitt, não é concebida simplesmente sob a forma da sub- 
sunção de um termo no outro ou da sua exclusão recíproca, mas como uma tensão em que os dois extremos se mostram mutuamente referidos. Trata-se, caso se prefira a expressão, de um vínculo dialético. Em outras palavras, a questão da ditadura, em Schmitt, está ligada à pergunta sobre fundamento concreto de uma ordem normativa abstrata.

Sendo assim, a suspensão dos obstáculos jurídicos e normativos que singulariza os poderes extraordinários do ditador se orienta por considerações de natureza normativa, muito embora não se baseie em nenhuma norma do direito. Ela se justifica, segundo Schmitt, em função de uma determinada "tarefa jurídica" (D:133), ou seja, a supressão de um estado de coisas que inviabiliza a vigência do direito. O estabelecimento de uma situação de exceção seria o resultado da necessidade de eliminar um "adversário [que] não se atém às normas do direito que o ditador reconhece como fundamento jurídico e como medida [für maßgebend]" (D:133). Na ditadura, portanto, se verificaria o paradoxo de que a defesa e a afirmação do direito possam exigir o reconhecimento de uma situação de fato em que as regras do direito simplesmente não se aplicam. Por esse motivo, Schmitt pode afirmar que "o problema da ditadura seria [...] o problema da exceção concreta" $(D: X V I I I)^{30}$. Por outro lado, a idéia de que a ditadura tem em vista a possibilidade de efetivação concreta do direito põe em evidência o fato de que, "como exceção, ela se mantém em uma dependência funcional em relação àquilo que nega" (D:XVII $)^{31}$. Na análise de Schmitt, a afirmação da dignidade teórica e jurídica da questão da ditadura está diretamente associada à perspectiva de que não é possível pressupor uma correspondência imediata entre justiça normativa e realidade concreta. Se a ditadura se faz necessária, é exatamente porque precisam ser criadas as condições efetivas em que a ordem jurídica possa se concretizar. Nisso reside, aos olhos de Schmitt, a sua própria justificação: "ela ignora, é certo, o direito, mas apenas para realizá-lo [zu verwirklichen]" (D:XVIII). Nesse sentido, a referência ao adversário parece-me central. Como já observei anteriormente, para Schmitt, não existe ordem normativa sem o estabelecimento de algum consenso em torno de princípios comuns. Todavia, a possibilidade-limite do estado de exceção tornaria evidente que as condições desse consenso não se criam mediante a persuasão racional. Dessa forma, o problema da ditadura traz consigo a questão do conflito e da violência como meio de concretização da ordem normativa. $O$ fato de a vigência dessa ordem exigir a eliminação daqueles que não reconhecem os seus 


\section{Bernardo Ferreira}

fundamentos normativos significa, para Schmitt, que o direito para se tornar efetivo não pode prescindir da sua própria negação ${ }^{32}$. Segundo ele,

“[...] entre a dominação da norma a ser realizada [Herrschaft der zu verwirklichenden Norm] e o método da sua realização [Verwirklichung] pode, portanto, existir uma oposição. De um ponto de vista jurídico-filosófico, aqui está a essência da ditadura, mais especificamente, na possibilidade geral de uma separação entre as normas do direito e as normas de realização do direito [Rechtsverwirklichung]" (D:XVII).

Essa característica da ditadura permite considerar de forma mais precisa o conceito de exceção no pensamento de Schmitt. Pelo que disse até agora, espero que esteja claro que, na exceção, a suspensão da ordem normativa não é o mesmo que uma renúncia à possibilidade de fundamentar juridicamente a experiência. Aqui, segundo Schmitt, a revogação da normalidade e, portanto, da vigência da ordem jurídica "é sempre algo de diferente de uma anarquia e de um caos" (PT:18) ${ }^{33}$. Longe de ser um estado de coisas que ignora toda fundamentação jurídica, a exceção se apresentaria como a situação extrema de um "nada normativo" (DarD:24) em que o direito, sem dar lugar à mera factualidade do real, reconhece, por assim dizer, a sua incapacidade de governá-la de acordo com a racionalidade das normas. Nessa perspectiva, segundo Giorgio Agamben (1997:26), o estado de exceção configuraria um caso-limite de indiferenciação entre uma situação de fato e uma situação de direito. No estado de exceção, as normas do direito emudecem, o que não significa que o seu lugar seja tomado pela crueza imediata de relações de força indiferentes a toda mediação jurídica. Por isso, Schmitt pode se referir à exceção ditatorial como "um problema da realidade concreta [konkreten Wirklichkeit], sem deixar de ser um problema jurídico" (D:133-134). Com efeito, na sua reflexão, o reconhecimento da "realidade concreta" é a condição para o estabelecimento de uma ordem igualmente concreta. Nesse quadro, o tema da exceção representa a tentativa de pensar uma situação em que o direito experimenta o seu limite ou então, como quer Carlo Galli (1996), se confronta com a sua origem não racional ${ }^{34}$.

No tema da exceção está, com certeza, um dos eixos do "realismo político" próprio do pensamento de Carl Schmitt. Por um lado, trata-se de uma situação extrema construída intelectualmente, que oferece um ponto de vista privilegiado para se pensar a questão do funda- 
mento da ordem jurídica. Mas não só. A busca de um fundamento concreto está indissoluvelmente ligada, no seu pensamento, à afirmação do caráter não normativo e, portanto, indeterminado da vida social e política. Em última análise, ele concebe a "realidade concreta" a partir do problema da exceção. Como o próprio Schmitt observa, "justamente uma filosofia da vida concreta não pode se retrair diante da exceção e do caso extremo, mas deve se interessar por ele na mais alta medida [...]. Na exceção, a força da vida real [wirklich Lebens] rompe a crosta de uma mecânica entorpecida na repetição" (PT:21).

Dessa forma, em oposição à generalidade abstrata do dever-ser normativo, o ser da "vida real" em Schmitt apresenta-se como algo que possui, por sua própria natureza, um caráter potencialmente excepcional, extraordinário. A "realidade concreta" é o terreno do imponderável e do contingente, daquilo que não obedece a nenhum critério racional de calculabilidade e dedutibilidade, não podendo ser delimitado e previsto com antecipação ${ }^{35}$. Nesse sentido, é significativa a imagem que Schmitt nos propõe da exceção: ela é, segundo ele, "o não-subsumível" (PT:19), o que "perturba a unidade e a ordem do esquema racionalista" (PT:20). Na exceção, a "vida real" mostra-se como algo que não pode ser contido dentro dos parâmetros de uma racionalidade normativa, mas que, ao mesmo tempo, precisa ser governada juridicamente. Assim, a premissa da falta de correspondência imediata entre justiça normativa e realidade concreta desdobra-se em uma reflexão sobre o potencial desestabilizador e, ao mesmo tempo, inovador da vida política. No pensamento de Schmitt, a existência política não possui fundamento ou, para empregar os termos de Roberto Racinaro (1986:160), não se apresenta "ontologicamente 'fixada'", manifestando-se, na exceção, sob a forma da crise, de uma ruptura da aparente naturalidade do continuum da vida ordinária. A questão do "concreto" em Schmitt está associada à impossibilidade de fundar a vida comum sobre bases incontroversas e à afirmação da necessidade de que a ordem reconheça o seu próprio fundo de desordem.

Esse caráter potencialmente excepcional e não normativo do conceito de konkreten Wirklichkeit (realidade/efetividade concreta) ganhará mais tarde no pensamento político de Carl Schmitt uma feição claramente existencial. Nesse sentido, sua discussão sobre o "conceito do 'político'" pode ser considerada como um desdobramento da sua análise a respeito do tema da exceção. Não por acaso, no livro Der Be- 


\section{Bernardo Ferreira}

griff des Politischen (O Conceito do Político), o caso de exceção (Ausnahmefall) será associado ao caso crítico (Ernstfall) do conflito entre amigos e inimigos (cf. BP:35, 39). À luz dessa perspectiva, a questão do "político" mostra-se indissociável da tentativa de incorporar à reflexão jurídica os problemas da "realidade concreta". O "existencialismo político" de Schmitt está diretamente ligado à sua preocupação com as condições da ordem e da sua validade concreta. O reconhecimento da natureza existencial e impermeável a toda mediação normativa da inimizade política constitui, a seu ver, a premissa de uma ordem mediada normativamente.

Ao mesmo tempo, a insistência de Schmitt na natureza extraordinária da idéia de "realidade concreta" permite qualificar de forma ainda mais precisa o sentido da recusa romântica da seriedade do real. A "Entwirklichung der Welt" ("esvaziamento da realidade do mundo") promovida pelo romântico está diretamente associada à sua crença na possibilidade de fundar toda a experiência das coisas em uma vivência subjetiva. Se o sujeito romântico pretende ser superior à realidade ou mesmo evadir-se dela é porque, nos diz Schmitt, ele se quer um "criador de mundos". Nisso, a produtividade estética do romantismo, a despeito da sua incompatibilidade com todo tipo de norma, se aproximaria do racionalismo normativista. A presunção de reduzir a "vida real" à abstração de um sistema normativo é, sob determinados aspectos, análoga ao despojamento da substância da realidade pela fantasia ocasional do indivíduo. Em ambos os casos, o mundo parece adquirir ordem e coerência interna, se resolvendo na produtividade estética do indivíduo ou na universalidade de um sistema normativo. Ao buscar no sujeito o fundamento prévio e a garantia da experiência, o romantismo ignora a contingência da vida concreta: sua evasão das determinações do real é, antes de tudo, uma recusa da indeterminação concreta da vida social e política.

Além disso, como observa Giacomo Marramao ${ }^{36}$, a ênfase de Schmitt na natureza existencial da "vida real" reveste o conceito de exceção de uma clara ambivalência. Ao pensar a exceção como algo irredutível às generalizações normativas, Schmitt a associa a um efeito de choque, de quebra da continuidade do tempo ordinário ${ }^{37}$. Ela traria consigo a possibilidade do novo, de uma experiência única e imediata, que, como tal, perturbaria a aparente evidência da regra que se repete no cotidiano. Não por acaso, Schmitt reconhece na exceção jurídica uma analogia com o milagre na esfera da religião. Em ambos os 
casos, dar-se-ia uma ruptura que, em razão da sua radical alteridade, do seu caráter absolutamente singular e extraordinário, abalaria a aparente naturalidade da norma geral e da vida cotidiana, a pontando para um "além" da mera identidade da experiência ordinária consigo mesma $^{38}$. Nessa perspectiva, a insistência de Schmitt na incomensurabilidade da exceção em relação ao geral é indissociável de uma valorização da sua natureza potencialmente inovadora ${ }^{39}$. Por outro lado, a suspensão das normas do direito pode ser interpretada em termos puramente defensivos, como um meio de preservação da ordem ameaçada.

Uma vez mais, a análise de Schmitt sobre a ditadura é ilustrativa dessa ambigüidade da exceção. Segundo ele, é possível distinguir dois tipos de ditadura: ditadura comissarial, em que a suspensão da ordem jurídica e os poderes extraordinários do ditador têm em vista a proteção de uma constituição sob ameaça. A exceção visa, aqui, liberar o terreno dos obstáculos jurídicos que impeçam o recurso às medidas necessárias ao restabelecimento da normalidade, ou seja, de uma situação de ordem e segurança públicas em que a constituição possa ter vigência. A ditadura comissarial, portanto, depende de uma constituição já existente, embora sua ação não esteja baseada na legalidade constitucional. $\mathrm{O}$ ditador pode suspender as normas vigentes e o exercício regular dos poderes constituídos, sem no entanto revogá-los. Ela é, nas palavras de Schmitt, uma "comissão de ação incondicionada de um pouvoir constitué" (D:143).

O mesmo já não ocorreria com o outro tipo de ditadura analisado por Schmitt: a ditadura soberana. Dessa vez, não se trata de salvaguardar a constituição existente, mas de criar uma nova. Estamos diante de uma ditadura de caráter revolucionário. Não por acaso, Schmitt reconhece na atuação da Convenção Nacional durante a Revolução Francesa, entre 1792 e 1795, o primeiro exemplo histórico de uma ditadura soberana. A exceção, nesse caso, não implica a mera suspensão da constituição vigente, mas a sua revogação. Como ele mesmo observa,

"[...] a ditadura soberana vê no conjunto da ordem existente a situação que ela quer eliminar através da sua ação. Ela não suspende uma constituição existente graças a um direito fundado nela - portanto, graças a um direito constitucional -, mas busca criar uma situação em que seja possível uma constituição que ela considera como a verdadeira 


\section{Bernardo Ferreira}

constituição. Ela não invoca uma constituição existente, mas uma constituição a implementar" (D:134).

A ditadura soberana, como se pode ver, não se baseia em poderes constituídos, já que ela age no sentido de uma ruptura com a ordem existente. Nesse caso, a ação do ditador encontra sua razão de ser e sua "fundamentação jurídica" (D:134) na existência de um poder não constituído, mas que, segundo Schmitt, é a fonte da própria ordem constitucional: o poder constituinte. Para ele, onde há poder constituinte há um "mínimo de constituição" (D:142). Dessa forma, a eliminação das condições adversas à expressão da vontade do pouvoir constituant é equivalente à criação de um estado de coisas em que o direito possa ter vigência, ainda que este não se apresente sob a forma de uma constituição instituída. Na ditadura soberana, portanto, o estado de exceção constitui-se em relação à própria ordem jurídica a ser implementada e tem em vista criar uma situação em que seja possível o livre exercício do poder constituinte ${ }^{40}$. Aqui, observa Schmitt, "primeiramente, devem ser criadas para [o] próprio povo as condições exteriores a fim de que o seu poder constituinte possa se tornar atual" ( D:142). O ditador, portanto, atua na condição de comissário do povo, ele age em nome da vontade constituinte, para eliminar as resistências políticas ao estabelecimento da nova ordem. Os poderes de exceção exercidos pelo ditador revolucionário apresentam-se igualmente sob a forma de uma comissão, no entanto, e esse é o ponto significativo: sua relação com o comitente se transforma.

Schmitt, na esteira do pensamento de Sieyès, concebe o pouvoir constituant como uma "força originária [Urkraft]" (D:139) do direito, capaz de gerar ordem e formas jurídicas, mas que não se deixa jamais fixar a si mesma. Ele seria, por definição, "informe" (D:140); caso contrário, estaríamos diante um órgão constituído. Tendo em vista sua superioridade em relação a todas as formas estabelecidas, o poder constituinte se apresentaria como "o organizador inorganizável" (D:139) ${ }^{41}$ A vontade constituinte do povo, nessa perspectiva, não pode exibir um conteúdo preciso, sem deixar de ser ilimitada e incondicionada. Assim, apesar da total dependência em relação ao seu comitente, o comissário do povo, segundo Schmitt, faz algo mais do que simplesmente transmitir uma vontade já definida, ele deve "formá-la [formieren]" $(D: 140)^{42}$. Em última análise, o conteúdo dessa comissão não pode ser delimitado e, devido à própria natureza da sua tarefa de formação da vontade constituinte, o ditador desfruta do "pleno poder 
absoluto, diante do qual todas as competências existentes desapare$c^{\prime}$ cm $^{\prime}(D: 114)$. Daí que a comissão do ditador assume, ainda que provisoriamente, um caráter soberano e, ao mesmo tempo, democrático. Estamos diante de "um comissário imediato do povo, um ditador que dita inclusive ao seu mandante, sem deixar de se legitimar por ele" $(D: X I X)^{43}$.

Na ditadura revolucionária, a eliminação dos obstáculos à efetivação do direito acaba por se confundir com a criação do próprio direito. Se for verdade, como Schmitt insiste, que a ditadura nega a norma que tem por função realizar, aqui, paradoxalmente, a norma que se nega ainda está por ser criada. O ditador, para usar os seus termos, age em nome de uma "constituição ideada [vorgestellten]" (D:146). Com isso, realiza-se, por assim dizer, uma passagem da esfera jurídica para a existencial e política. Já não é, como no caso da ditadura comissarial, a preservação do direito constituído que justifica a ruptura do direito, mas a existência política do poder constituinte do povo como fonte originária do direito ${ }^{44}$. Ao mesmo tempo, na ditadura soberana se evidenciaria com toda a clareza a fonte da legitimidade da ação ditatorial. Ainda que o ditador aja em nome de uma constituição existente ou por instituir, ainda que, portanto, o fim da sua ação seja "correspondente a uma representação normativa" (D:XVII), os meios para a realização desse fim, os seus poderes extraordinários, não se legitimam em termos de qualquer norma jurídica. Pelo contrário, eles significariam a negação dessas normas. Para Schmitt, essa legitimidade só pode ser o resultado da existência de "uma autoridade suprema, juridicamente capaz de suspender [aufzuheben] o direito e autorizar uma ditadura, ou seja, capaz de permitir uma exceção concreta" ( $D: X V I I I)$.

Na ditadura revolucionária, essa dimensão político-existencial, concretizada na figura do poder constituinte, assume, como apontei anteriormente, o lugar da inovação e, cabe agora acrescentar, o papel de fundamento último de validade da própria ordem jurídica. Porém, esse mesmo fator que funda a ordem contém em si um potencial de desestabilização e a torna problemática. A natureza informe e "efetivamente inconstituível" (D:140) do poder constituinte é característica desse paradoxo. Ele é a fonte de todas as normas jurídicas, mas nunca se esgota nas formas que origina, as quais, como assinala Schmitt, "a qualquer momento pode romper" (D:139). Exige uma atividade de formação, mas não pode ser fixado em uma moldura constitucional. Ao afirmar a indeterminação e a excepcionalidade 


\section{Bernardo Ferreira}

da "vida real", o pensamento de Schmitt equilibra-se de maneira instável e tensa entre o reconhecimento da ausência de fundamento da "realidade concreta" e a exigência de constituição de uma ordem; entre a afirmação da natureza informe da existência política e a necessidade da sua formação; entre a defesa da irredutibilidade da exceção à regra e a busca de uma condução normativa da vida social e histórica. Nesse contexto, a singularidade absoluta e a indeterminação concreta da "vida real" apresentam-se, simultaneamente, como a condição e o obstáculo para a construção de uma ordem. É também nesse contexto que o tema da decisão assume importância central. Vejamos este ponto.

Como observei anteriormente, para Schmitt, o ponto de vista da exceção nos mostraria que nenhuma norma pode conter em si mesma o fundamento da sua validade. A situação-limite da suspensão do direito no estado de exceção colocaria o problema da instauração da própria ordem normativa. Nesse quadro, a questão da validade já não poderia ser pensada em termos da auto-suficiência da norma, mas traria consigo a pergunta pela instância de validação da ordem. A possibilidade de situações que escapam a toda delimitação normativa imporia a necessidade de uma decisão que estivesse em condições de ditar concretamente as fronteiras do direito. Aqui, insiste Schmitt, "a decisão se liberta de todo vínculo normativo e se torna absoluta em um sentido próprio" (PT:18). Decidir, nessa perspectiva, seria algo mais do que a mera aplicação de uma norma. Pelo contrário, pois "de um ponto de vista normativo, a decisão nasce de um nada" (PT:37-38). Este fato se deveria a duas razões fundamentais: em primeiro lugar, em uma situação de conflito, no "nada normativo" do estado de exceção, não haveria nenhuma possibilidade de um consenso em torno de princípios últimos que servissem de fundamento para uma decisão. Nesse caso, nos diz Schmitt,

“[...] naturalmente, todos querem apenas o direito, a moral, a ética e a paz; ninguém quer cometer injustiças; mas a única questão in concreto interessante é sempre: quem vai decidir no caso concreto o que é o direito? onde está a paz? o que é uma perturbação ou ameaça da paz? com que meios elas são eliminadas? quando é que uma situação está normal e 'pacificada'? etc." 45 .

Uma vez que, para Schmitt, o conflito não pode ser resolvido em nome de uma norma reconhecida por todos como incondicionalmen- 
te válida, o fundamento último da decisão não obedeceria a critérios de certeza racional. Pelo contrário, ela "se torna nesse momento independente de uma fundamentação argumentativa e adquire um valor autônomo" (PT:37). A decisão é, ao mesmo tempo, um ato de interpretação, capaz de atribuir significado concreto aos conceitos que estruturam a vida coletiva. Todavia, semelhante interpretação é, antes de tudo, um ato de autoridade. Não se trata do simples reconhecimento de algo já dado, mas contém em si um "momento constitutivo" (PT:37). A construção da ordem pública seria indissociável de um processo de produção e imputação de sentido, através do qual se eliminariam possibilidades alternativas de interpretação. Como o próprio Schmitt observa, tratando-se de

"[...] conceitos políticos decisivos, interessa justamente quem os interpreta, define e aplica; quem, através da decisão concreta, diz o que é paz, desarmamento, intervenção, ordem pública e segurança. Trata-se de uma das mais importantes manifestações da vida jurídica e espiritual da humanidade em geral o fato de que aquele que possui o verdadeiro poder também pode determinar por si mesmo os conceitos e palavras. Cæsar dominus et supra grammaticam: César também é senhor da gramática" ${ }^{46}$.

Em segundo lugar, não haveria como subsumir as diferentes situações que concretamente exigem uma decisão na generalidade abstrata de um preceito moral ou de um princípio jurídico. A existência de uma norma geral seria aqui de pouca utilidade, porque, em última análise, "a circunstância que torna necessária uma decisão permanece um momento determinante e independente" (PT:36). Para Schmitt, a circunstância de uma autêntica decisão desafia toda delimitação normativa. Aceitar o ponto de vista da exceção significaria, portanto, reconhecer o caráter literalmente extraordinário da decisão, a qual se situaria, antes de tudo, no domínio daquilo que não pode ser previsto, daquilo que não pode ser antecipado. Na ótica racionalista da "normalidade de princípio", a ruptura com a ordem normal se apresentaria como algo infenso à compreensão racional. Para Carl Schmitt, porém, o fato de que a situação fora da norma implica uma ruptura com a ordem tornaria patente o papel da decisão no estabelecimento de uma "situação ordinária". Assim, a premissa da impossibilidade de uma correspondência imediata entre norma e realidade característica do conceito de exceção teria como outro lado da moeda 


\section{Bernardo Ferreira}

a função mediadora da decisão como a condição da efetividade de uma ordem normativa.

A análise da questão da validade da ordem em termos da decisão tem alguns desdobramentos no pensamento de Schmitt que, a meu ver, merecem ser considerados.

Em primeiro lugar, ao afirmar que a vigência do direito não pode ser dissociada das condições concretas da "normalidade factual", Schmitt transforma a decisão em um fator de estabelecimento de uma situação normal. Decidir, nessa perspectiva, implica criar e impor uma "configuração normal das relações de vida" em que as regras jurídicas possam ser válidas. A decisão assume, com isso, um caráter eminentemente político. Ela nasce de um nada normativo e tem no conflito a premissa da sua própria efetividade. Assim, ao aproximar, como já vimos, o caso de exceção e a possibilidade extrema do conflito político, ele associa igualmente a decisão sobre a exceção e a decisão sobre o inimigo. A eliminação do inimigo e a construção de um consenso por exclusão acabam por se apresentar como condições de criação da própria normalidade ${ }^{47}$.

Em segundo lugar, ao insistir na idéia de que a decisão cria a situação normal em que as normas podem ter validade, Schmitt recusa, como já observei em diversas oportunidades, a imagem de princípios normativos incondicionalmente válidos. Dessa maneira, o problema transfere-se do fundamento da decisão para a decisão como fundamento. Esta concepção decisionista do direito estaria sintetizada em uma fórmula extraída do capítulo 26 do Leviatã, retomada insistentemente por Schmitt: "Auctoritas, non veritas facit legem" ("A autoridade, não a verdade, faz a lei"). Assim, ao se originar de um "nada normativo", a decisão funda, de uma forma literalmente autoritária, a própria ordem normativa. Ao criar as condições concretas de vigência do direito, ela cria o próprio direito. Segundo Schmitt, para que o direito possa governar a realidade, é preciso - já assinalei este ponto - que a situação seja calculável e que exista alguma estabilidade das "relações de vida"; é preciso, portanto, instituir concretamente uma ordem normal e pacífica. No entanto, o estabelecimento de semelhante ordem não se dissocia de uma decisão sobre o que é o direito, o interesse público, a paz. A criação de uma normalidade factual não é um dado anterior à a plicação do direito aos fatos, mas constitui um ato de conformação jurídica da realidade. No entanto, como não existe norma pré- 
via que sirva de fundamento da decisão, esse ato de conformação jurídica da realidade se confunde com um ato de vontade. A existência de uma vontade pública capaz de decidir sobre o que é e onde está a ordem passa a ser condição de validade dessa mesma ordem. Com o decisionismo, portanto, a pergunta pelas condições de validade de uma ordem normativa desdobra-se em dois temas estreitamente associados. Por um lado, a idéia da primazia da decisão sobre a norma tende a ser formulada em termos da anterioridade da existência da unidade política em relação aos seus aspectos normativos (cf. PT:18-19), ou então, de maneira ainda mais abstrata, como a "superioridade do existencial sobre a pura normatividade" (VL:107). Por outro lado, trata-se de saber quem é o sujeito dessa vontade capaz de criar a ordem. Um pouco mais à frente, retornarei a esta última questão.

Por fim, parece-me necessário considerar o significado ontológico que o tema da decisão possui no pensamento de Schmitt. Para ele, a existência de uma decisão capaz de se impor publicamente e dotada de legitimidade apresenta-se como uma maneira de conferir algum tipo de determinação à indeterminação da vida social e política. A decisão é, nessa perspectiva, um ato que extrai a sua força da contingência da "realidade concreta" e, ao mesmo tempo, interrompe a sua deriva, criando um estado de coisas em que seja possível a constituição normativa da vida comum. Retomando termos já empregados, acredito que a decisão pode ser pensada como um fator de "fixação ontológi$c a^{\prime \prime}$ da realidade concreta.

A essa altura, imagino que já esteja claro para o leitor como a análise da decisão, em Carl Schmitt, se coloca no extremo oposto da sua caracterização do romantismo. Enquanto a produtividade estética do sujeito romântico aprofundaria a indeterminação da realidade concreta, criando um mundo inteiramente ocasional e desprovido de qualquer ponto de referência fixo, a decisão implicaria o reconhecimento de uma instância última e de uma vontade pública capazes de instituir ordem no mundo. Portanto, à privatização, ao imobilismo, à passividade, à indefinição, ao niilismo, ao "eterno diálogo" (PT:59) romântico, Schmitt contrapõe uma imagem da decisão como a ação política por excelência; uma ação que se confronta com a necessidade de uma intervenção pública na realidade, de uma direção substantiva da experiência concreta, de uma condução normativa da vida social. Por outro lado, ainda que a decisão em Schmitt possa ser concebida como um contraponto à contingência da "vida real", ela não significa 


\section{Bernardo Ferreira}

a recuperação de um estado de coisas ontologicamente garantido. É evidente a natureza assumidamente paradoxal da tentativa de buscar na decisão uma via política que assegure consistência ontológica a um mundo sem substância. A decisão, já sabemos, emana de um vazio normativo e, embora seja o fundamento de validade da ordem, não possui em si mesma nenhum fundamento. Ao conceber a decisão desprovida de fundamento, Schmitt transforma o reconhecimento da indeterminação em um pré-requisito da determinação da própria ordem.

No estado de exceção, portanto, a ação humana ocorreria sem nenhum parâmetro e seria levada a se confrontar com a sua absoluta precariedade e, ao mesmo tempo, com o seu próprio potencial criativo. "Liberta de todo vínculo normativo", a decisão no estado de exceção pode ser pensada como uma ação que implica a incerteza e o risco e, ao mesmo tempo, o máximo do arbítrio humano. Na falta de pontos de apoio seguros, o papel do arbítrio e da capacidade de deliberação pessoal seria levado ao extremo e, por assim dizer, se apresentaria em "estado puro", pois aqui não haveria lugar para se conceber a ação como derivada de conteúdos normativos prévios, ou seja, como uma "auto-aplicação da norma vigente" (DarD:23). Com isso, o problema da exceção, no pensamento de Schmitt, está acompanhado de uma espécie de elogio da produtividade da ação humana, entendida, acima de tudo, como uma decisão pessoal em uma situação de colapso das referências normativas. Nesse contexto, a ação é, antes de tudo, "uma decisão pura, absoluta, que não argumenta [nicht räsonierende], não discute, não se justifica e, portanto, criada a partir do nada" (PT:69). No entanto, ao contrário da arbitrariedade distintiva da produtividade ocasional do sujeito romântico, a ação do sujeito da decisão em Schmitt é criadora de ordem; trata-se de uma ação dotada de eficácia pública. Sob determinados aspectos, parece-me possível dizer que o ponto de vista do estado de exceção radicaliza a indeterminação das sociedades modernas para evidenciar o lugar constitutivo do sujeito e de uma decisão pessoal na criação da ordem pública. Todavia, sujeito da decisão não é um agente qualquer, mas alguém que, segundo Schmitt, possui competência para tanto (ele emprega os termos Zuständigkeit, Befugnis, Kompetenz). Mesmo assim, uma pergunta permanece: afinal, em que consiste essa competência do sujeito da decisão? Esta questão nos conduz inevitavelmente ao tema da soberania no pensamento de Carl Schmitt. 
Até aqui, procurei analisar o problema do fundamento de uma ordem normativa na reflexão jurídico-política de Schmitt tendo em vista os temas da exceção e da decisão. Essas duas questões, como havia afirmado no início da discussão, podem ser interpretadas a partir do seu contraponto com a recusa romântica do real e sua renúncia à decisão. No entanto, um ponto central continua por ser explorado, muito embora já venha se insinuando ao longo da minha exposição: trata-se da questão da soberania e, por conseguinte, do sujeito da decisão. Na verdade, a análise, como procurei fazer, tratando separada e sucessivamente dos temas da exceção e da decisão, não pode nos iludir quanto ao fato de que Schmitt os pensa em conjunto e em função do tema da soberania. A decisão genuína, para ele, é sempre uma decisão soberana, e a verdadeira decisão soberana é aquela que remete ao estado de exceção. Mais precisamente: "soberano é quem decide sobre o estado de exceção" [Souverän ist, wer über den Ausnahmezustand entscheidet] (PT:13).

Esta afirmação categórica, que, como uma espécie de decisão prévia, abre o capítulo inicial de Teologia Política, merece maior atenção. Todavia, não pretendendo retomar a análise precedente, gostaria apenas de me concentrar em dois problemas específicos: o primeiro refere-se ao "quê" da decisão soberana - o que está em jogo na idéia de uma "decisão sobre o estado de exceção"? O segundo diz respeito ao "quem" da soberania - afinal, quem é o soberano?

Schmitt concebe a noção de soberania como um Grenzbegriff, um conceito-limite ${ }^{48}$ construído a partir de um ponto de vista extremo. Para ele, ela se refere a uma instância de decisão última em um quadro de falência das referências normativas, ou seja, no "nada normativo" do caso de exceção. Em uma situação em que todas as decisões tendem a se tornar equivalentes, o "monopólio da decisão última" (PT:19) pelo soberano significaria a possibilidade de sustar a multiplicação de interpretações sobre a natureza do interesse público e acabar com o conflito em torno dos princípios da própria ordem, instituindo autoritariamente a normalidade e os parâmetros da existência coletiva. Daí, a idéia de que "a questão da soberania é a questão da decisão de um conflito existencial" (VL:371), ou seja, de um conflito que não pode ser solucionado em função de critérios normativos, mas cuja resolução é, ela mesma, a origem de padrões normativos. Nesse sentido, pode-se dizer, com perdão da redundância, que a decisão do soberano é decisiva, pois, como observa Schmitt, comentando Hobbes, ela "cria o 


\section{Bernardo Ferreira}

direito, ao decidir a luta em torno do direito" (D:21). O ponto de vista extremo da exceção tornaria patente a importância da soberania como esse lugar de decisão sobre a natureza da própria ordem pública. O fato de a ação do soberano se dar em um quadro de colapso dos fundamentos normativos não se confunde, para Schmitt, com o exercício arbitrário da força. Como ele nos diz, para o decisionista, "a fonte de todo 'direito', ou seja, de todas as normas e ordenamentos que daí decorrem, não é o comando [Befehl] como comando, mas a autoridade e a soberania de uma decisão última, que está associada ao comando" (DarD:21).

O caráter último da decisão soberana lhe confere uma autoridade que não permite reduzi-la ao simples exercício da força, ou seja, ela não se resume a um estado de fato, mas seria, por assim dizer, conforme o direito. No entanto, uma questão continua sem resposta: o que confere força de direito à decisão soberana já que a sua expressão mais acabada se verifica no "nada normativo" do estado de exceção? Na ausência de um fundamento prévio e sendo equivalentes todas as decisões alternativas, o que torna efetivamente última a decisão soberana é a sua capacidade de se impor sobre as demais e conquistar reconhecimento público. Com isso, Carl Schmitt é levado a formular o seu problema em termos, eu diria, deliberadamente aporéticos: a decisão soberana tem a força do direito porque cria as condições de vigência do próprio direito e não porque se funda em um direito antecedente. $\mathrm{Ou}$, para empregar o paradoxo que ele nos propõe em Teologia Política: "a autoridade [...] não precisa ter direito, para criar o direito" (PT:19). Ao agir, o soberano realiza um movimento de conformação da "vida real" e, embora a sua decisão nasça de uma exceção concreta, não se deixa diluir na natureza informe e imediata desta última ${ }^{49}$.

Para Schmitt, essa natureza última da decisão soberana e, portanto, a sua capacidade de instituir as condições concretas de vigência do direito se evidenciariam na sua competência para a revogação da ordem vigente: se o soberano decide sobre a natureza da ordem é porque ele está em condições de decidir sobre o estado de exceção. Porque não pode ser subsumida, circunscrita ou antecipada, a exceção precisa ser declarada, ou melhor, decidida. Mais precisamente: a exceção, já sabemos, não pode ser deduzida de nenhum princípio geral, não há parâmetro algum a partir do qual seria possível reconhecer antecipadamente uma determinada situação como excepcional. Por isso, a decisão, para Schmitt, jamais tem um significado meramente 
declarativo, ela, pelo contrário, constitui o estado de exceção. Não se trata do simples reconhecimento de um certo estado de coisas: é o soberano quem decide quando as normas não mais se aplicam, quem determina o momento em que uma ordem normativa, por não dar conta da "vida real", precisaria ser suspensa. Ele decide sobre (über) o estado de exceção. Nesse sentido, ao instituir o estado de exceção, o soberano faz algo mais do que constatar uma situação de conflito que escapa à normalidade, ele se torna parte do próprio conflito e o assume como a condição de estabelecimento da ordem. A sua ação tornaria evidente que a norma não é universalmente válida e que não contém em si o seu próprio fundamento. A contraface, por conseguinte, da decisão sobre o estado de exceção é a decisão sobre a normalidade. O mesmo soberano que estabelece o estado de exceção, definindo uma situação como anormal, estaria em condições de determinar em que consiste a ordem pública, quando ela foi restabelecida, restaurada. Dessa forma, como o próprio Schmitt observa, o soberano, contraditoriamente, "está fora do ordenamento jurídico normalmente em vigor, todavia, faz parte dele, porque é competente [zuständig] para a decisão sobre se a constituição in toto pode ser suspensa" (PT:14).

Assim, a analogia entre exceção e milagre ganha uma qualificação adicional. Em ambos os casos, a ruptura com a continuidade da experiência cotidiana pressupõe "o reconhecimento de uma ação e de uma intervenção extraordinárias, semelhantes àquelas do a deo excitatus" ${ }^{\prime 50}$. A exceção traria consigo a imagem de uma instância externa à própria ordem das coisas, capaz de suspender o seu funcionamento corriqueiro e, com isso, instaurar uma situação excepcional. Por outro lado, essa ruptura assume um caráter demiúrgico: aquele que rompe com as regras existentes é, ao mesmo tempo, capaz de criar a ordem a partir do nada. A suspensão das normas no estado de exceção permitiria pensar o sujeito da decisão como alguém que, à imagem e semelhança de Deus, decide sobre o que é e onde está a ordem ${ }^{51}$.

Portanto, a crítica à metafísica do sujeito moderno como um fator de dissolução da ordem não é incompatível com o papel que Schmitt atribui a uma decisão pessoal no estabelecimento da ordem pública. O que ele recusa, na verdade, é a idéia de que a crise dos fundamentos da vida coletiva se possa resolver através da sua fundamentação no sujeito individual e na esfera do privado. Na verdade, como venho observando, sua reflexão sobre o problema da ordem jurídico-política é indissociável da pergunta pelo lugar do sujeito da deci- 
são. No pensamento de Schmitt, o soberano pode ser visto como o antípoda da absolutização do indivíduo no mundo liberal burguês. Tanto em um caso como no outro, estamos diante de figuras secularizadas de Deus. Todavia, enquanto a transformação do sujeito individual em ponto último de legitimação da realidade aniquila todo e qualquer fundamento, pulveriza e, finalmente, anula o Deus tradicional da metafísica cristã, a decisão soberana, mal ou bem, significa, para Carl Schmitt, um caminho de volta até ele. O soberano, nessa perspectiva, pode ser visto como um "metassujeito" (Jay, 1993:52), supra-individual e público, como um lugar de decisão pessoal a ser ocupado no interior da ordem jurídico-política e, ao mesmo tempo, situado acima dela.

No entanto, para fazer jus à complexidade da reflexão de Schmitt, é preciso reconhecer que esse lugar de decisão última que distingue a soberania não implica uma posição previamente definida e assegurada. Tentarei ser um pouco mais claro: se for verdade que a soberania envolve uma instância de decisão última, por outro lado, como insiste Schmitt em diferentes oportunidades, a competência do soberano não pode ser circunscrita e definida previamente. A ação do soberano remete à situação de exceção e, como tal, não pode ser antecipada e regulamentada. Sua competência é "por princípio, ilimitada", pois diz respeito à "suspensão do conjunto da ordem existente" (PT:18). Com isso, a questão das atribuições da soberania converte-se na pergunta pelo sujeito da soberania ${ }^{52}$. Mais precisamente: "quem decide sobre as competências não reguladas constitucionalmente, ou seja, quem é competente quando o ordenamento jurídico não dá resposta alguma à pergunta pela competência?" (PT:17).

Imagino que não será difícil reconhecer que, para Schmitt, essa pergunta só pode ter uma resposta política. Em última análise, a competência do soberano depende da sua capacidade de se impor no estado de exceção e instaurar um quadro de normalidade. Sua decisão é última, já assinalei este ponto, porque exclui todas as decisões alternativas. Formulando a questão nos termos que Schmitt utilizará posteriormente para caracterizar o "político": a competência do soberano está associada à sua capacidade de monopolizar a diferenciação entre amigo e inimigo. Dessa forma, o lugar da soberania, da instância de decisão última no ordenamento jurídico, é um lugar a ser ocupado, ou melhor, é um lugar que se define existencial e politicamente através da própria decisão soberana. O soberano não existe como entidade jurídica 
previamente constituída, mas se constitui no próprio ato de decisão. Nesse contexto, me parece que Giuseppe Duso tem razão quando afirma que, em Schmitt, "a subjetividade se manifesta na decisão em ato, esta coincide com a crítica do sujeito como fundamento, como substância que se determina antes e independentemente da decisão e da política" $(1981: 63)^{53}$. Dessa forma, a crítica de Schmitt ao sujeito romântico pode ser ampliada em relação àquilo que eu disse há pouco. Não se trata apenas de uma crítica antiindividualista à privatização da experiência no mundo liberal burguês, mas também uma crítica à idéia mesma de um fundamento prévio da ordem. Por oposição à moderna metafísica do sujeito que privatiza e subjetiviza o princípio de ordem, a soberania oferece um princípio "objetivo" de ordem. Porém, o fato de a competência do sujeito da soberania depender da cisão instituída pela própria decisão impõe o reconhecimento de que essa subjetividade política nasce de uma fratura e conserva em si a memória dessa fratura ${ }^{54}$. A unidade e a identidade do sujeito da decisão depende da sua abertura para o imponderável da exceção e para o imperativo da exclusão, que continuamente negam as idéias mesmas de identidade e unidade.

(Recebido para publicação em outubro de 2002)

\section{NOTAS}

1. Legenda dos textos de Carl Schmitt citados:

Der Begriff des Politischen - BP

Die Diktatur - D

Die geistesgeschichtliche Lage des heutigen Parlamentarismus - GlhP

Hugo Preuss. Sein Staatsbegriff und seine Stellung in der Deutschen Staatslehre - HP

Legalität und Legitimität - LL

Politische Romantik - PR

Politische Theologie - PT

Positionen und Begriffe - PuB

Über die drei Arten des rechtswissenschaftlichen Denkens - DArD

Verfassungslehre - VL

2. Karl Löwith já havia sublinhado essa questão, ao destacar que "as exposições de Schmitt são essencialmente 'polêmicas', ou seja, não se dirigem apenas casualmen- 


\section{Bernardo Ferreira}

te a isso ou àquilo para clarificar criticamente a sua opinião, mas a sua própria 'exatidão' baseia-se totalmente naquilo contra o qual se dirigem" (Löwith, 1960:63).

3. Cito a partir da segunda edição revista, publicada em 1925. A esta segunda edição Carl Schmitt acrescentou um importante prefácio e incorporou um ensaio de 1920 denominado "Politische Theorie und Romantik" ("Teoria Política e Romantismo"), que veio a ser a terceira parte do livro.

4. "A estrutura do espírito romântico" ("Die Struktur des romantischen Geistes") é o título do capítulo central do livro de Schmitt.

5. "Der Begriff der modernen Demokratie in seinem Verhältnis zum Staatsbegriff" (1924), in PuB:27.

6. Segundo Schmitt, a análise do romantismo "deve, assim como toda situação importante da moderna história do espírito [Geistesgeschichte], começar com Descartes" (PR:62).

7. Este é o subtítulo que Schmitt dá à primeira parte do seu capítulo sobre a "estrutura do espírito romântico".

8. Os trechos citados correspondem ao subtítulo que Carl Schmitt dá, no índice do seu livro, à parte onde ele discute as questões suscitadas pela filosofia de Descartes: “O problema filosófico da época: a oposição entre ser e pensamento e a irracionalidade do real" (PR:23).

9. "Staatsethik und pluralistischer Staat", in PuB:153. Em PT, Schmitt fala da "imagem metafísica que uma determinada época faz do mundo" (PT:50).

10. Michele Nicoletti, comentando a análise de Carl Schmitt sobre o racionalismo moderno no livro Romantismo Político, formula a questão nos seguintes termos: "o racionalismo [...] tende a pôr-se como chave explicativa do real, mas esse racionalismo, na análise schmittiana acaba por conduzir a um fracasso: ao invés de lançar uma ponte entre ser e pensamento, ele encerra o pensamento em um formalismo abstrato e entrega a realidade a um mecanicismo bruto" (Nicoletti, 1990:113). Essa "realidade", que escapa ao racionalismo moderno, mas à qual ele em última análise aspira, geralmente aparece no texto designada pela palavra de origem latina Realität. Com isso, pode-se dizer que Schmitt tende a estabelecer uma distinção conceitual entre "realidade" entendida como "substância ontológica", normalmente designada como Realität, e "realidade" no sentido mais empírico, normalmente designada pela palavra de origem germânica Wirklichkeit - ainda que esta não seja uma distinção rígida e o uso destes conceitos possa variar ao longo do texto.

11. Segundo Schmitt, seria possível reconhecer quatro reações diferentes ao racionalismo: uma de natureza filosófica, em que se destacariam Spinoza e Hegel; uma de perfil místico e antifilosófico, associada às figuras de Madame Guyon e Antoinette Bourignon e a filósofos como Fénelon e Poiret; uma oposição histórico-tradicionalista, que encontraria em Vico o seu principal representante; e, por fim, um movimento de caráter emocional-estético, ao qual, como afirmei há pouco, o romantismo pertenceria.

12. Para a referência à lírica como a forma de produtividade própria ao sentimento romântico da vida e da natureza, ver $P R: 66$. 
13. Nesse sentido, concordo com Catherine Colliot-Thélène, quando ela observa que, na análise de Schmitt, o subjetivismo constitui o "fundo comum do racionalismo moderno e do romantismo" (Colliot-Thélène, 1992:284).

14. As expressões "romance infindável" e "jogo de palavras" pertencem a Novalis. Schmitt recolhe a primeira do seguinte fragmento de Novalis: "todos os acasos da nossa vida são matéria com a qual podemos fazer o que quisermos, tudo é o primeiro elo de uma cadeia interminável, o início de um romance infindável" (apud PR:92).

15. Segundo Catherine Colliot-Thélène, essa caracterização da ironia romântica e a própria imagem do romantismo como uma recusa do mundo objetivo em nome da independência subjetiva mantêm evidentes pontos de contato com a crítica de Hegel aos românticos (cf. Colliot-Thélène, 1992).

16. Para a noção de "ocasionalismo subjetivizado", ver $P R: 18-19$.

17. A referência aqui é a idéia de uma "conceptualidade radical [radikaler Begrifflichkeit]" (PT:50), que Schmitt apresenta no seu livro Politische Theologie, de 1922. Essa idéia implicaria, em linhas gerais, uma análise dos conceitos que levasse em conta o seu núcleo metafísico e teológico e, dessa forma, "descobr[ir] a estrutura última, radicalmente sistemática e compar[ar] essa estrutura conceitual com a elaboração conceptual da estrutura social de uma determinada época" (PT:50). Nesse sentido, concordo com a observação de Carlo Galli de que a remissão de Schmitt à ordem burguesa "não é tanto um dado sociológico, quanto metafísico" (Galli, 1996:198). É com base nessa perspectiva "metafísica" ou, caso se queira, "teológico-política" que se entende, a meu ver, a aproximação que Schmitt estabelece entre romantismo, liberalismo, racionalismo. Não se trata da afirmação de uma mera equivalência e identidade, ou seja, Schmitt não nos diz, por exemplo, que romantismo e liberalismo são a mesma coisa. Trata-se, isso sim, de reconhecer nesses diferentes movimentos a presença da mesma "estrutura ideal". Uma vez mais, penso que Carlo Galli formulou o problema de maneira precisa ao dizer que "o que Schmitt critica no nexo que aproxima romantismo, racionalismo e liberalismo é o fato de que esses complexos histórico-políticos [...] pressupõem, mais ou menos abertamente, que o sujeito seja a instância última da política e da realidade, e que exista uma espécie de garantia a priori de que através do diálogo entre sujeitos (e da relação entre o sujeito e o mundo) possa se realizar plenamente uma ordem" (idem:200).

18. Segundo Schmitt, "no núcleo dessa fantástica superioridade do sujeito encontra-se a renúncia a toda transformação ativa do mundo real, uma passividade" (PR:167; ver, também, PR:119).

19. O livro sobre o catolicismo foi publicado em 1923, ou seja, no ano anterior ao prefácio à segunda edição de Romantismo Político (o prefácio traz a data de setembro de 1924), do qual foram extraídas as citações referentes à questão da Repräsentation.

20. Essa é a leitura que Luiz Costa Lima, na seqüência de Karl Heinz Bohrer, faz da crítica de Schmitt ao caráter não representativo da arte romântica (cf. Costa Lima, 1993:150). Para a idéia de que a crítica de Schmitt está marcada pela nostalgia de uma ordem em que as referências da vida social estão asseguradas de antemão e “autoritariamente fixadas", ver Colliot-Thélène (1992:279).

21. Para observações do mesmo gênero, ver, por exemplo: DarD:14; BP:72; VL:9, 56, 90. 


\section{Bernardo Ferreira}

22. Cf. "Zu Friedrich Meineckes Idee der Staatsräson" (1926), in PuB:57; LL:33; VL:37. Como observa George Schwab, em Schmitt, "toda afirmação religiosa, filosófica ou moral precisa de interpretação" (Schwab, 1989:46).

23. "Zu Friedrich Meineckes Idee der Staatsräson" (1926), in PuB:53.

24. Em $D A r D$, de 1934, Schmitt reafirma esse ponto: "a normalidade da situação concreta, regulada pela norma, e do tipo concreto por ela pressuposto não é, portanto, apenas um pressuposto externo, a ser desconsiderado do ponto de vista da ciência jurídica, mas uma característica jurídica essencial, interna, da validade da norma e uma determinação normativa da própria norma. Uma norma pura, desligada de toda situação e tipo [situationlose und typenlose], seria um absurdo jurídico" (DarD: 20). Um dos alvos dessa insistência na importância normativa do caráter concreto da "normalidade factual" é a "teoria pura do direito", do jurista austríaco Hans Kelsen. O normativismo de Kelsen é uma das principais referências de Schmitt na sua discussão sobre o fundamento de validade de um sistema normativo. Sobre Schmitt e Kelsen, pode-se consultar entre outros: Hofmann (1999); Portinaro (1982); Caldwell (1997); Kervégan (1995); Beaud (1993); Araujo (1990).

25. Hasso Hofmann considera que o conceito de "normal" no pensamento de Schmitté "sociológico", pois "ele não pensa que a situação concreta esteja sujeita à validade absoluta de um valor, mas indica a efetividade de um princípio unitário de estrutura da realidade social" (Hofmann, 1999:96). Creio, no entanto, que essa caracterização da normalidade como um conceito sociológico pode induzir a equívocos, já que, como veremos, para Schmitt, esse "princípio de estruturação" é constituído pela ação política. Nesse sentido, parece-me preferível qualificar essa normalidade de política. Essa é a perspectiva, por exemplo, de Heiner Bielefeldt, que afirma que Schmitt pensa a "normalidade política como base da normatividade legal" (Bielefeldt, 1996:383).

26. Como o próprio Schmitt observa, no estado de exceção, "os dois elementos do conceito 'Rechts-Ordnung' se defrontam e demonstram a sua independência conceptual” (PT:19). Essa insistência na separação entre ordenamento e ordenamento jurídico tem, entre outros alvos, a redução do Estado ao direito realizada por Hans Kelsen.

27. "Staatsethik und pluralistischer Staat", in PuB:159-160.

28. Para uma discussão da centralidade do problema da realização do direito no pensamento jurídico de Carl Schmitt com referência aos seus textos anteriores a 1919 (com particular destaque para Der Wert des Staates und die Bedeutung des Einzelnen), ver Hofmann (1999); Nicoletti (1990); Duso (1988).

29. Segundo Schmitt, "se, em tempos normais, o meio concreto para alcançar um resultado concreto (por exemplo, o que a polícia está autorizada a fazer para a manutenção da segurança pública) pode ser calculado com uma certa regularidade, no caso de necessidade [Notfall], pode-se apenas dizer que o ditador está autorizado a fazer precisamente tudo o que é necessário conforme a situação das coisas. Aqui não importam mais as considerações jurídicas, mas apenas o meio adequado para um resultado concreto no caso concreto. Aqui também o procedimento [Vorgehen] pode ser falso ou correto, mas essa apreciação se refere apenas ao fato de se as medidas [Maßnahme] são corretas num sentido técnico-objetivo [sachtechnischen], isto é, se elas são adequadas ao fim [zweckmäßig]" (D:11). 
30. Em outra oportunidade, Schmitt irá afirmar que a "a ditadura é necessariamente 'estado de exceção'” (D:XVI).

31. Cf., também, D:146. Em função disso, Schmitt afirma que "em um sentido geral, pode-se denominar de ditadura toda exceção em relação a uma situação concebida como justa" ( $D: 146)$. Esse, não custa insistir, é o ponto que separa, aos olhos de Schmitt, a ditadura do despotismo. Segundo ele, "uma ditadura que não dependa de um resultado correspondente a uma concepção normativa, porém a se realizar concretamente, que não tenha por objetivo se fazer supérflua é um despotismo qualquer" (D:XVII).

32. A referência ao adversário a ser eliminado é central em um outro aspecto. Segundo Schmitt, a tendência do Estado de Direito liberal seria cada vez mais regulamentar o exercício dos poderes de exceção. Com isso, a ditadura torna-se sinônimo de "estado de sítio" e a constituição não é suspensa, mas apenas alguns dos direitos de liberdade. Como observa Grigoris Ananiadis, aos olhos de Schmitt, o equívoco de semelhante situação reside no fato de que, no estado de sítio do mundo liberal, os adversários da ordem jurídico-política continuam a ser tratados como cidadãos e não como inimigos a serem eliminados (cf. Ananiadis, 1999:125); para uma discussão histórica do problema do "estado de sítio", ver o cap. VI de $D$ ).

33. Cf., também, PT:20.

34. Hasso Hofmann faz uma observação semelhante ao dizer que Schmitt "confronta a doutrina do Estado com o seu fundo niilístico e irracionalístico" (1999:112).

35. Nessa discussão, acompanho algumas idéias de Racinaro (1986).

36. Sigo aqui de perto as considerações de Marramao (1990). Pode-se consultar também Marramao (1981) (posteriormente recuperado, com algumas alterações, como capítulo do livro Poder e Secularização); Marramao (1995; 1997) (estes dois últimos textos recuperam e reelaboram o texto de 1990).

37. Para a aproximação entre o conceito de exceção e as idéias de "choque, agora, subitaneidade [suddenness]", próprias das vanguardas artísticas e intelectuais do começo do século XX, ver Bredekamp (1999:253). Para esse intérprete, uma das razões da atração de Walter Benjamin pelo pensamento de Schmitt estaria justamente nessa imagem da exceção como um evento único, que não se enquadra na sucessão ordinária dos acontecimentos e produz uma "cessação do tempo ordinário" (ibidem). Segundo Jacob Taubes, a experiência da história tanto em Benjamin quanto em Schmitt estaria determinada pela idéia de Jetztzeit (cf. Taubes, 1996:38).

38. Para a aproximação entre exceção e milagre, cf. PT:43.

39. Como observa Marramao, a afirmação por Schmitt da natureza existencial da vida concreta traz consigo uma ênfase no "momento 'inovador', de ruptura beneficamente catastrófica" (Marramao, 1990:35). No final do primeiro capítulo de PT, Schmitt reproduz um longo trecho de um "teólogo protestante" do século XIX (trata-se de Kierkegaard), que é significativo dessa valorização da exceção em face do geral: "a exceção explica o geral e a si mesma. E, caso se queira estudar o geral corretamente, é necessário procurar por uma real exceção. Ela traz à luz tudo muito mais claramente do que o próprio geral. Há muito estamos fartos do eterno palavrório sobre o geral; existem exceções. Se elas não podem ser explicadas, também não é possível explicar o geral. Freqüentemente não se nota a dificuldade, por que o geral 


\section{Bernardo Ferreira}

sequer é pensado com paixão, mas com uma cômoda superficialidade. A exceção, pelo contrário, pensa o geral com uma paixão enérgica" (PT:21).

40. Segundo Schmitt, "na ditadura revolucionária, a constituição a ser implementada pela ditadura assim como pelo sempre presente pouvoir constituant está suspensa" (D:142). Um pouco mais adiante, Schmitt observa que "no estado de coisas por meio do qual a ditadura se justifica, o conteúdo em si problemático do poder constituinte não está efetivamente presente [aktuell nicht vorhanden], segundo seus próprios pressupostos" (D:142-143).

41. Mais adiante, Schmitt afirma: "do abismo infinito e inabarcável do seu poder se originam sempre novas formas, que a qualquer momento ele pode romper e nas quais o seu poder jamais se delimita definitivamente. Ele pode querer o que lhe aprouver, o conteúdo do seu querer tem sempre o mesmo valor jurídico do conteúdo de uma determinação constitucional. Ele pode, portanto, intervir como bem entender através da legislação, da administração da justiça ou de meros atos fáticos [faktischen]. Ele se torna o titular ilimitado e ilimitável dos jura dominationis, que nem sequer no caso de necessidade [Notfall] precisam ser limitados. Ele jamais constitui a si mesmo, mas sempre constitui os outros" (D:139). Essa concepção do poder constituinte será um dos pilares do livro Teoria da Constituição, de 1928.

42. Não por acaso, Schmitt considera que a paradoxal figura do législateur, no Contrato Social de Rousseau, embora não concebida em termos de uma comissão, seria distintiva do processo de transição do tipo clássico de ditadura comissarial para a ditadura soberana (cf. cap. III de $D$ ).

43. Sobre esse ponto, ver, também, VL:59-60. A afirmação por Schmitt da compatibilidade entre democracia e ditadura tem como contraface a dissociação entre liberalismo e democracia, que será insistentemente afirmada em GlhP. Na ditadura soberana, assinala Schmitt referindo-se a um discurso de Barère, de 1793, “o povo, na verdade, exerce a ditadura sobre si mesmo" ( $D: 148)$. No apêndice da segunda edição de 1928, “Die Diktatur des Reichspräsidenten nach Artikel 48 der Weimarer Verfassung" ("A ditadura do presidente do Reich segundo o artigo 48 da constituição de Weimar"), Schmitt retoma a discussão sobre a ditadura soberana e qualifica a própria atuação de uma assembléia constituinte como um caso de ditadura soberana. Segundo ele, "enquanto semelhante assembléia não concluir o seu trabalho, a constituição, ela detém toda competência imaginável. Todo o poder do Estado [Staatsgewalt ] está reunido em suas mãos e pode se apresentar imediatamente sob a forma que quiser. Uma normação [Normierung] e uma repartição exaustivas das competências e das funções estatais ainda não existem; o poder constituinte do povo ainda não se vinculou a limites constituídos e a assembléia constituinte pode, portanto, de acordo com o seu próprio juízo fazer valer a plenitudo potestatis" (D:236). O mesmo ponto de vista é desenvolvido em VL:59-60.

44. Nesse sentido, parece-me que Carlo Galli tem razão quando afirma que, na ditadura soberana, a "a exceção não é jurídica, mas político-existencial", de tal forma que "o problema jurídico da Rechtsverwirklichung atinge o extremo - tornando-se problema político" (Galli, 1996:579).

45. "Zu Friedrich Meineckes Idee der Staatsräson" (1926), in PuB:57.

46. "Völkerrechtliche Formen des modernen Imperialismus" (1932), in PuB:202.

47. Cf. "Staatsethik und pluralistischer Staat", in PuB:159-160.

\section{4}


48. Para a idéia de Grenzbegriff, cf. PT:13.

49. Nesse sentido, Michele Nicoletti identifica um componente pragmático no pensamento de Schmitt. Segundo ele, em Schmitt, "a verdade de um fato não está na sua coerência em relação a uma ordem interior ou exterior preexistente de tipo natural ou metafísica [...], mas em relação a uma finalidade histórica e socialmente posta (não a uma finalidade ideal), em relação à sua capacidade de instituir e realizar uma ordem concreta" (Nicoletti, 1990:20-21).

50. "Zu Friedrich Meineckes Idee der Staatsräson" (1926), in PuB:53. A expressão "a deo excitatus" pode ser traduzida como "impelido por Deus".

51. Posteriormente, no momento em que Schmitt tende a se distanciar da perspectiva decisionista, esse caráter demiúrgico da soberania receberia uma formulação ainda mais enfática: segundo ele, o decisionismo pressupõe "a representação consciente de uma total desordem, de um caos, que só se transforma em lei e ordem através de uma pura decisão" (DarD:22). Nessa perspectiva, observa ele, para o decisionista, “a decisão soberana é começo absoluto, e o começo (no sentido de $\grave{\alpha} \rho \chi \eta)$ não é nada mais do que decisão soberana" (DarD:24). A referência à expressão grega arché é significativa, pois esta palavra tanto pode significar princípio no sentido de começo, como princípio no sentido de fundamento.

52. “O caso de exceção, o caso não definido no ordenamento jurídico vigente, pode na melhor das hipóteses ser designado como caso de extrema necessidade, de ameaça à existência do Estado, ou algo semelhante, mas não pode ser delimitado de acordo com os fatos [tatbestandmässig]. Só este caso torna atual a pergunta pelo sujeito da soberania, ou seja, a pergunta pela soberania em geral" (PT:13-14, ênfases minhas).

53. Logo adiante, o mesmo comentador observa: "a subjetividade não [está] acima e fora da função da decisão, e, por isso, não se [pode] individuar abstratamente e $a$ priori um sujeito legitimador da decisão" (idem:63).

54. Para uma associação entre decisão e corte a partir da própria etimologia da palavra, ver o texto já citado de Marramao (1990:36). 


\section{Bernardo Ferreira}

\section{REFERÊNCIAS BIBLIOGRÁFICAS}

\section{a. Textos de Carl Schmitt}

Der Begriff des Politischen. Berlin, Duncker \& Humblot, 1996, 6ª ed. (texto de 1932, reimpresso a partir da edição de 1963, que foi acrescida de um novo prefácio e de notas adicionais).

Die Diktatur. Von den Anfängen des modernen Souveränitätsgedankens bis zum proletarischen Klassenkampf. Berlin, Duncker \& Humblot, 1994, 6 $6^{\underline{a}}$ ed. (reimpressão da $2^{\underline{a}}$ ed. de 1928).

Die geistesgeschichtliche Lage des heutigen Parlamentarismus. Berlin, Duncker \& Humblot, 1996, 8ª ed. (reimpressão da $2^{\text {a }}$ ed. de 1926).

Hugo Preuss. Sein Staatsbegriff und seine Stellung in der Deutschen Staatslehre, Tubigen, J. C. B. Mohr, 1930.

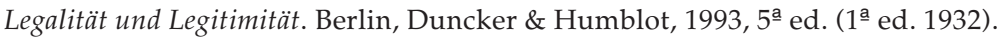

Politische Romantik. Berlin, Duncker \& Humblot, 1989, 6 $6^{\underline{a}}$ ed. (reimpressão da $2^{\underline{a}}$ ed. de 1925).

Politische Theologie. Berlin, Duncker \& Humblot, 1996, $7^{\underline{a}}$ ed. (reimpressão da $2^{a}$ ed. de 1934).

Positionen und Begriffe. Berlin, Duncker \& Humblot, 1988, $2^{\underline{a}}$ ed. (1aㅡ ed. 1940).

Römischer Katholizismus und politische Form. Stuttgart, Klett-Cotta, 1985 (reimpressão da $2^{\text {a }}$ ed. de 1925).

Über die drei Arten des rechtswissenschaftlichen Denkens. Berlin, Duncker \& Humblot, 1993, $3^{\text {a }}$ ed. (1 $1^{\text {a }}$ ed. 1934).

Verfassungslehre. Berlin, Duncker \& Humblot, 1989, $7^{\text {a }}$ ed. (1ํㅡㄹ ed. 1928).

\section{b. Geral}

AGAMBEN, Giorgio. (1997), Homo Sacer. Paris, Seuil.

ANANIADIS, Grigoris. (1999), "Carl Schmitt and Max Adler", in C. Mouffe (org.), The Challenge of Carl Schmitt. London, Verso.

ARAUJO, Jose Estevez. (1990), La Crisis del Estado de Derecho. Schmitt en Weimar. Barcelona, Ariel.

BEAUD, Olivier. (1993), "Carl Schmitt ou le Juriste Engagé" , in C. Schmitt, Théorie de la Constitution. Paris, PUF.

BIELEFELDT, Heiner. (1996), “Deconstruction of the 'Rule of the Law': Carl Schmitt's Philosophy of the Political". Archiv für Rechts- und Sozialphilosophie, no 82.

BREDEKAMP, Horst. (1999), “From Walter Benjamin to Carl Schmitt, via Thomas Hobbes". Critical Inquiry, no 25.

CALDWELL, Peter C. (1997), Popular Sovereignty and the Crisis of German Constitutional Law. Durham, Duke University Press. 
COLLIOT-THÉLÈNE, Catherine. (1992), “Critique du Subjectivisme e du Fondement de l'Action: Carl Schmitt et Hegel”. Les Cahiers du Fontenay, no 67 / 68 .

COSTA LIMA, Luiz. (1993), Limites da Voz: Montaigne, Schlegel. Rio de Janeiro, Rocco.

DUSO, Giuseppe. (1981), "Tra Costituzione e Decisione: La Soggettività in Carl Schmitt", in G. Duso (org.), La Politica oltre lo Stato: Carl Schmitt. Veneza, Arsenale. . (1988), La Rappresentanza: Un Problema di Filosofia Politica. Milão, Franco Angeli.

GALLI, Carlo. (1996), Genealogia della Politica. Bolonha, Il Mulino.

HOFMANN, Hasso. (1999), Legittimità contro Legalità. Nápoles, ESI.

JAY, Martin. (1993), “The Reassertion of Sovereignty in a Time of Crisis: Carl Schmitt and Georges Bataille", in Force Fields. New York, Routledge.

KERVÉGAN, Jean-François. (1995), “La Critique Schmittienne du Normativisme Kelsénien", in C. M. Herrera (org.), Le Droit, le Politique. Autour de Max Weber, Hans Kelsen, Carl Schmitt. Paris, L'Harmattan.

LÖWITH, Karl. (1960), “Der okkasionelle Dezisionismus von C. Schmitt” (1935). Gesammelte Abhandlungen: zur Kritik der geschichtlichen Existenz. Stuttgart, W. Kohlhammer Verlag.

MARRAMAO, Giacomo. (1981), “Carl Schmitt: La Decisione senza Presupposti e il Fantasma dello Stato", in G. Duso (org.), La Politica oltre lo Stato: Carl Schmitt. Veneza, Arsenale.

__ (1990), “L'Esilio del Nomos. Profilo critico di Carl Schmitt”. Behemoth, no 7.

(1995), Poder e Secularização. São Paulo, Editora UnESP.

(1997), Céu e Terra. Genealogia da Secularização. São Paulo, Editora UnEsP.

NICOLETTI, Michele. (1990), Trascendenza e Potere. La Teologia Politica de Carl Schmitt. Brescia, Morcelliana.

OAKES, Guy. (1986), “Translator's Introduction”, in C. Schmitt, Political Romanticism. Cambridge, The MIT Press.

PORTINARO, Pier Paolo. (1982), La Crisi dello Jus Publicum Europaeum. Milão, Comunità.

RACINARO, Roberto. (1986), “Esistenza e decisione in Carl Schmitt”. Il Centauro, no 16.

SCHWAB, George. (1989), The Challenge of Exception (2 ${ }^{\mathrm{a}}$ ed.). New York, Greenwood.

TAUBES, Jacob. (1996), In Divergente Acordo. Scritti su Carl Schmitt. Macerata, Quodlibet. 


\title{
Bernardo Ferreira
}

\author{
ABSTRACT \\ Subject and Order: Romanticism and Decisionism in the Thinking of \\ Carl Schmitt
}

The objective of this article is to discuss the link in the work of Carl Schmitt between the critique of romanticism and the reflection on the themes of sovereignty and decision. Based on an analysis of some key issues in the books Politische Romantik (Political Romanticism), Politische Theologie (Political Theology), and Die Diktatur (The Dictatorship), the article analyzes how, in Carl Schmitt, romanticism and decisionism represent counterpoised conceptual universes, which refer to each other in various aspects. The attempt is thus to highlight both the structurally controversial nature of the German jurist's ideas and the close ties between his legal/political theory and his critique of the liberal-bourgeois order as a synthesis of modernity.

Key words: Carl Schmitt; romanticism; sovereignty; dictatorship; modern state

\section{RÉSUMÉ}

Sujet et Ordre: Romantisme et Décisionnisme dans la Pensée de Carl Schmitt

Dans cet article, on examine la jonction, dans l'oeuvre de Carl Schmitt, entre sa critique du romantisme et sa réflexion sur les thèmes de la souveraineté et de la décision. À partir de l'analyse de certains problèmes centraux de ses livres Politische Romantik (Romantisme Politique), Politische Theologie (Théologie Politique) et Die Diktatur (La Dictature), on essaie de dégager comment romantisme et décisionnisme composent, chez Carl Schmitt, des univers conceptuels opposés, qui, sous plusieurs aspects, se renvoient les uns aux autres. On cherche ainsi à souligner, d'un côté, la nature structurellement polémique de la construction des idées chez ce juriste allemand et, d'un autre, les liens étroits entre sa théorie juridico-politique et sa critique de l'ordre libéral-bourgeois en tant que synthèse de la modernité.

Mots-clé: Carl Schmitt; romantisme; souveraineté; dictature; État moderne 